\title{
SOURCE-TO-SINK: AN EARTH/MARS COMPARISON OF BOUNDARY CONDITIONS FOR EOLIAN DUNE SYSTEMS
}

\author{
GARY KOCUREK \\ Department of Geological Sciences, University of Texas, Austin, Texas 78712 USA \\ e-mail: garyk@mail.utexas.edu \\ AND \\ RYAN C. EWING \\ Division of Geological \& Planetary Sciences, California Institute of Technology, MC 170-25, \\ Pasadena, California 91125 USA \\ *Present address: University of Alabama, Department of Geological Sciences, Tuscaloosa, Alabama 35487 USA
}

\begin{abstract}
Eolian dune fields on Earth and Mars evolve as complex systems within a set of boundary conditions. A source-to-sink comparison indicates that although differences exist in sediment production and transport, the systems largely converge at the dune-flow and pattern-development levels, but again differ in modes of accumulation and preservation. On Earth, where winds frequently exceed threshold speeds, dune fields are sourced primarily through deflation of subaqueous deposits as these sediments become available for transport. Limited weathering, widespread permafrost, and the lowdensity atmosphere on Mars imply that sediment production, sediment availability, and sand-transporting winds are all episodic. Possible sediment sources include relict sediments from the wetter Noachian; slow physical weathering in a cold, water-limited environment; and episodic sediment production associated with climatic cycles, outflow events, and impacts. Similarities in dune morphology, secondary airflow patterns over the dunes, and pattern evolution through dune interactions imply that dune stratification and bounding surfaces on Mars are comparable to those on Earth, an observation supported by outcrops of the Burns formation. The accumulation of eolian deposits occurs on Earth through the dynamics of dry, wet, and stabilizing eolian systems. Dry-system accumulation by flow deceleration into topographic basins has occurred throughout Martian history, whereas wetsystem accumulation with a rising capillary fringe is restricted to Noachian times. The greatest difference in accumulation occurs with stabilizing systems, as manifested by the north polar Planum Boreum cavi unit, where accumulation has occurred through stabilization by permafrost development. Preservation of eolian accumulations on Earth typically occurs by sediment burial within subsiding basins or a relative rise of the water table or sea level. Preservation on Mars, measured as the generation of a stratigraphic record and not time, has an Earth analog with infill of impact-created and other basins, but differs with the cavi unit, where preservation is by burial beneath layered ice with a climatic driver.
\end{abstract}

KEY woRDs: Eolian, Earth, Mars, complex systems, boundary conditions

\section{INTRODUCTION}

The growing body of high-resolution images from satellites and surface missions shows that the surface of Mars is a cold, hyperarid desert and that eolian processes have played a dominant role in development of its geomorphic surface and stratigraphic record. Because eolian and cryogenic processes on Mars are commonly interrelated, the closest Earth analog is the McMurdo Dry Valleys of Antarctica, and significant insights have been gained from studies of eolian (Bourke et al. 2009; Bristow et al. 2010a, 2010b), permafrost (e.g., Marchant et al. 2002, Levy et al. 2006), weathering (e.g., Gibson et al. 1983, Marchant and Head 2007), and other dynamic systems in Antarctica. There are, however, important differences between Antarctica and the environmentally far more extreme Mars, and limits exist for analogs per se, because no two environments, separated by time or space, are ever exactly the same on Earth, and this is even less so for planetary comparisons.

A more conceptual approach to understanding eolian systems on Mars, one that does not use Earth analogs, is to consider these as sourceto-sink complex systems operating within a set of boundary conditions. Complex systems are typically dissipative systems involving a large number of elements governed by nonlinear dynamics, which operate within a set of external environmental variables or boundary conditions. The boundary conditions within which the system evolves affect the geomorphic expression and stratigraphic record of the system over a wide range of spatial and temporal scales (Werner 2003). Because no two systems ever share exactly the same boundary conditions, no two systems are ever exactly the same. Based on this thinking, each unique solution is a case study, but broad comparisons can be made based upon planetary-scale boundary conditions. Conversely, evolving environmental conditions on Mars can be reconstructed from the geomorphic and stratigraphic record of eolian systems. Because of the dominance of eolian processes on Mars, the eolian record may be the primary vehicle for interpreting planetary history, and, conceivably, planetary resurfacing may well be driven by eolian cycles.

This article explores the geomorphic and stratigraphic nature of eolian dune systems on Mars by way of a source-to-sink comparison of Earth/Mars boundary conditions (Fig. 1). The suspended (i.e., dust) component of the Martian eolian transport system is not considered. The overall conclusion is that although sediment sourcing and grain transport on Mars and Earth are significantly different, these planetary eolian systems largely converge at the dune and dune-field pattern levels, but again differ in modes of accumulation and preservation. The primary product of this article is a body of questions that arise from the Earth/Mars comparison, questions that may help to focus future work. In addition, the comparison of eolian systems evolving within planetary environments as different as Earth and Mars elucidates the dynamics of eolian systems themselves.

\section{SOURCING EOLIAN SYSTEMS}

\section{Earth}

The boundary conditions on Earth that yield sediment for eolian dunes include abundant water, dynamic atmospheric transfer of water 


\section{Aeolian Systems: Source-To-Sink}

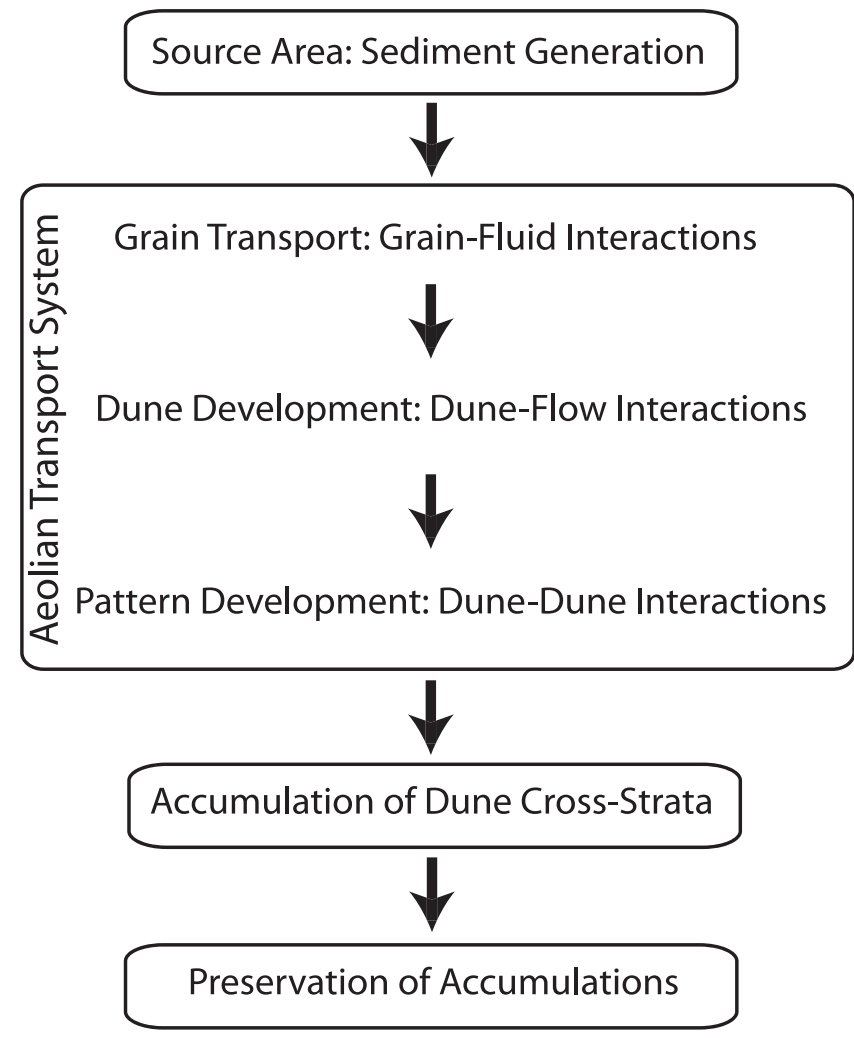

FIG. 1.-Flow diagram for source-to-sink eolian dune systems. At each stage of the source-to-sink route, differing sets of boundary conditions affect the system dynamics.

from oceans to continents, and warm temperatures, such that C-cycle chemical weathering, subaqueous erosion, and transport by fluvial systems dominate the surface. Because of the dominant role of water, most eolian systems are sourced directly or indirectly (via coastal processes) by fluvial systems (see discussion in Lancaster [1995; p. 88-90]). Eolian deflation primarily becomes significant once sources of sand have been emplaced by subaqueous processes. A minority of dune fields have been sourced directly by wind erosion of poorly consolidated sedimentary strata, but few (if any) dune fields have arisen solely through wind deflation of bedrock.

Weathering, erosion, and fluvial transport operate within a larger, slower-paced set of boundary conditions of tectonism, sea level, and climate (Fig. 2A). Changes in these boundary conditions cause temporal and spatial changes in source areas and dune fields. Because of these changes and the internal dynamics of dune fields, the antiquity of deserts on Earth is measured in $10^{2}$ to $10^{7}$ years, specific dune fields exist for $10^{1}$ to $10^{5}$ years, and individual dunes persist for $<10^{0}$ to $10^{5}$ years. The Namib (Ward et al. 1983) and the Atacama (Alpers and Brimhall 1988) are probably the oldest deserts on Earth, dating to at least the Miocene. Many major dune fields date to only the Last Glacial Maximum, which was a time of major resurfacing in the eolian realm (e.g., Kocurek 1999). The oldest dated dunes are linear dunes in Australia $(\sim 200 \mathrm{ka})$, although numerous cycles of activation and stabilization are evident internally (Nanson et al. 1992).

The temporal relationship between sediment source and dune-field construction can be conceptualized by the "sediment state" of the system (Kocurek and Lancaster 1999), and this relationship is described as one of the three following types: (1) contemporaneous, (2) lagged in time, or (3) a mix of contemporaneous and lagged sediment influx (Fig. 3A-C). For example, throughout its long history, the Namib has been sourced contemporaneously by the Orange River via coastal processes (Lancaster and Ollier 1983, Bluck et al. 2007). White Sands in New Mexico has been sourced by a mix of lagged sediment influx that occurred with deflation of lake-bed accumulations during regressions and contemporaneous influx from shorelines and exposed playa flats (Langford 2003). The Sahara has arguably received a lagged fluvial source at two scales. Quaternary Milankovitch cycles cause humid periods during which fluvial sediments are stored; during subsequent arid periods these stored sediments are reworked and source dune fields as lagged influx. The original major sourcing of the Sahara, however, probably lay with Pliocene reworking of extensive Miocene fluvial deposits, which were emplaced during the coincidence of active tectonism and the last major humid period of the region (Kocurek 1998).

Two other boundary conditions complete the sediment state of any eolian system: (1) the transport capacity of the wind and (2) the volume of sediment available on the surface for eolian transport (Fig. 3A-C). On Earth, the frequency of sand-transporting winds is high, and it is only the magnitude of the wind that varies spatially over the globe and temporally through climatic cycles (e.g., Milankovitch). Sediment availability is most commonly limited by vegetation, but a near-surface water table, surface cementation, and surface armoring by coarse grains are also common factors. Because of the high frequency of sandtransporting winds, once sediment is made available for transport by, for example, the onset of aridity or marine regression, if the sediment source is not regularly replenished it is generally exhausted rapidly, and dune-field constructional events are relatively short-lived (Kocurek and Lancaster 1999).

\section{Mars}

Significant volumes of sediment have been generated on Mars, as evident by (1) eolian, fluvial, and other depositional features on the surface, (2) the presence of a sedimentary stratigraphic record, and (3) the fact that there is little exposed bedrock on Mars (Edwards et al. 2009). The emerging image of sediment generation on Mars, however, indicates very different boundary conditions than prevailed on Earth during the Phanerozoic. The common occurrence of very ancient (i.e., Archean equivalent) rock on the surface of Mars in itself attests to very slow weathering rates. The potential for and nature of sediment generation on Mars, however, has evolved. There is significant evidence that during the Noachian $(\sim>3.5$ b.y.) Mars was wetter, and possibly warmer, with a denser atmosphere. Global change occurred during the late Noachian toward an increasingly cold, desiccated planet during the Hesperian and Amazonian. Whereas spot estimations of Noachian weathering rates are comparable to slow denudation rates on Earth, estimated Hesperian/Amazonian rates are orders of magnitude lower (Golombek and Bridges 2000, Golombek et al. 2006).

Satellite (e.g., Edgett and Malin 2000, Malin and Edgett 2006, Bridges et al. 2007, Bandfield and Feldman 2008) and surface (e.g., Greeley et al. 2000, 2004; Bell et al. 2004; Levy et al. 2009) images clearly show evidence for physical weathering driven by eolian abrasion, impact shattering, thermal stress, permafrost processes, gravity-driven mass wasting, and salt weathering. The relative roles of the major processes of physical weathering through time can be speculated upon with planetary evolution (Fig. 2B).

Chemical weathering has occurred overall within a cold, waterlimited, low-pH S-cycle (Hurowitz and McLennan 2007, McLennan and Grotzinger 2008), during which chemical reactions were incomplete (Madden et al. 2004, Tosca and Knoll 2009) and perhaps 
A. Earth
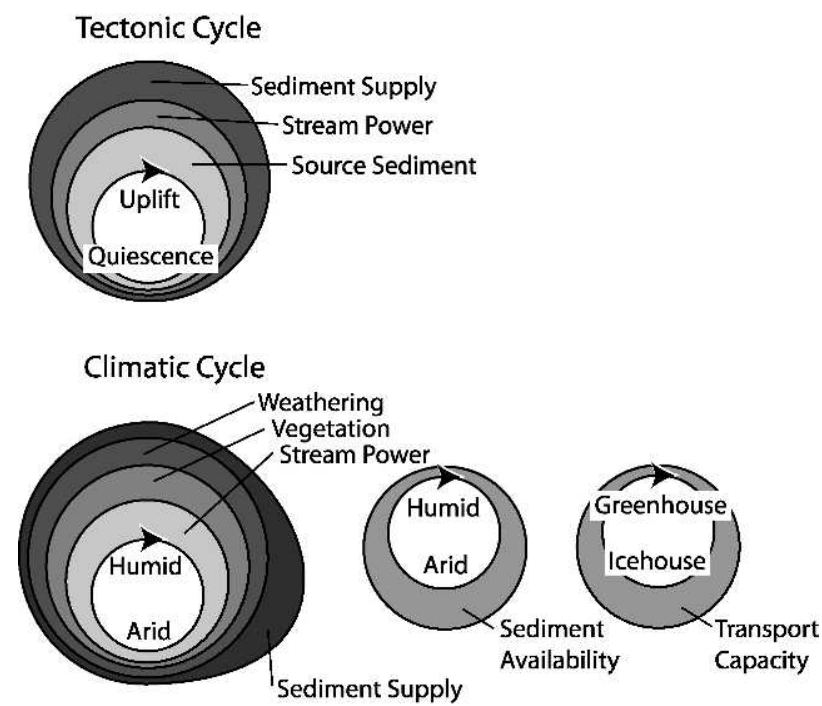

Eustatic Cycle
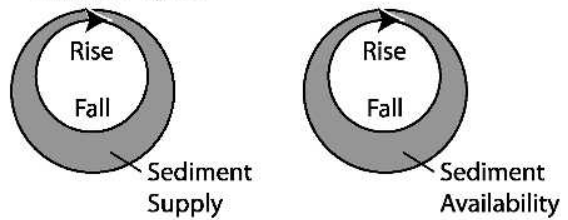

B. Mars

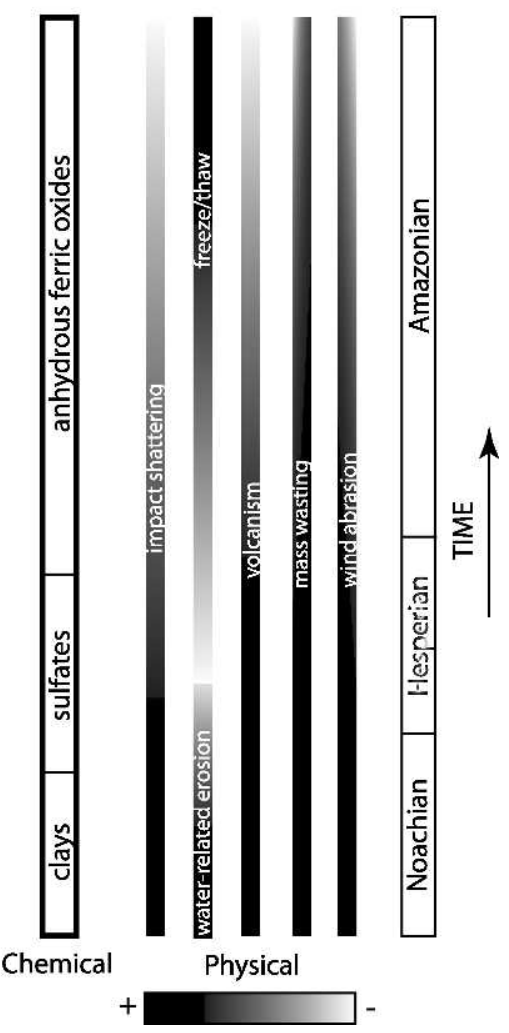

FIG. 2.- Sources of eolian sediment. (A) Earth, where rates of sediment generation vary with tectonic, climatic, and eustatic cycles. Tectonic uplift creates enhanced source-strata exposure and stream power for erosion to yield greater sediment supply. During a climatic cycle, greatest sediment supply typically occurs with the transition from humid to arid (Langbein and Schumm 1958), whereas sediment availability is greatest with aridity, and wind transport capacity is greatest during Icehouse stages. Both sediment supply and availability increase with lowered relative sea level because of enhanced erosion with lowered base level and increased shelf exposure, respectively. Modified from Kocurek (1999). (B) Mars showing eras of chemical weathering from Bibring et al. (2006) and postulated variations in types of physical weathering. Impact shattering, water processes, and volcanism may have dominated Noachian physical sediment production, whereas permafrost, Eolian, and mass-wasting processes probably dominate during the Amazonian.

short-lived episodes terminated by freezing and/or evaporation (Zolotov and Mironenko 2007). The most comprehensive interpretation of the general evolution of chemical weathering on Mars comes from global mineralogical mapping in which (1) a Noachian "phyllosian era" characterized by aqueous alteration and clay-mineral generation, yields to (2) a Hesperian "theiikian era" characterized by sulfate generation and (3) a late Hesperian-Amazonian "siderikian era" characterized by the formation of anhydrous ferric oxides in slow, superficial weathering without liquid water (Fig. 2B; Bibring et al. 2006).

Combining the potential for sediment generation from both physical and chemical weathering over time on Mars, three distinct eolian sediment states can be postulated (Fig. 3D-F). First, following an Earth analog, the primary episode of dune-field construction would have been contemporaneously or somewhat lagged in time with Noachian enhanced sediment generation (Fig. 3D). In this scenario, dune fields would have been sourced by deflation of fluvial, deltaic, and shoreline deposits, as has occurred during Earth history. Reworking of these original dune fields would have continued, but few additional dune fields would have been emplaced once Noachian sediment sources were exhausted. Given the abundance of dune fields on Amazonian terrain, however, this sediment-state scenario alone cannot account for the Martian eolian record.

In a sediment state that departs significantly from an Earth analog, eolian dune-field construction has occurred throughout Martian history, including those dune fields associated with Noachian events, but continuing through the Amazonian via sediment generated by very slow weathering processes (Fig. 3E). Unlike on Earth, where sediment is removed from the terrestrial surface through tectonism, burial, or transport to ocean basins, this "slow-cumulative" model allows for the aggregate of billions of years of slow weathering to remain on the surface. In this scenario, new dune fields would have arisen where sufficient sediment collected on the surface, albeit over protracted time intervals. This sediment state also falls short in explaining the occurrence of eolian dune fields because the post-Noachian Martian surface appears to have been far more dynamic, especially in response to specific events.

The sediment state that best incorporates enhanced Noachian sediment production and subsequent slow "background" weathering, but also envisions significant periods of dune-field generation on postNoachian Mars, is an "episodic" model in which sediment generation, wind transport, and sediment availability are all episodic on a variety of 
Aeolian Sediment State: Earth
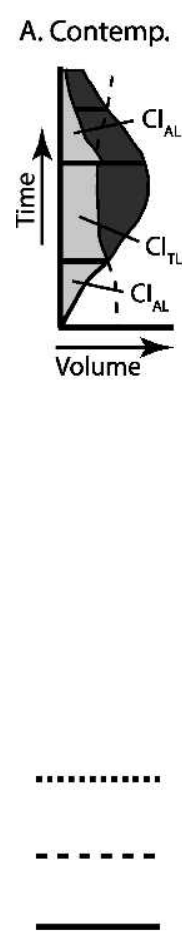

B. Lagged

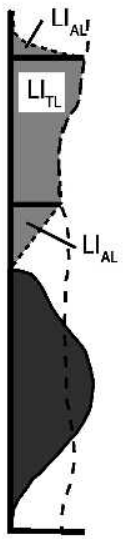

Sediment Availability

Transport Capacity of Wind

Sediment Generation
Aeolian Sediment State: Mars
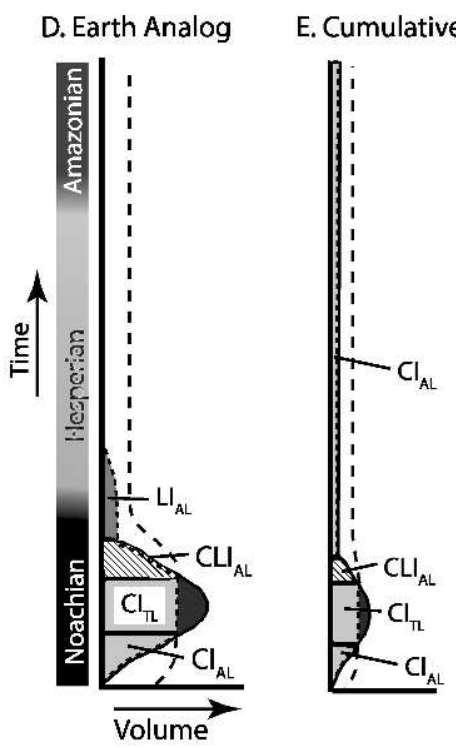

F. Episodic
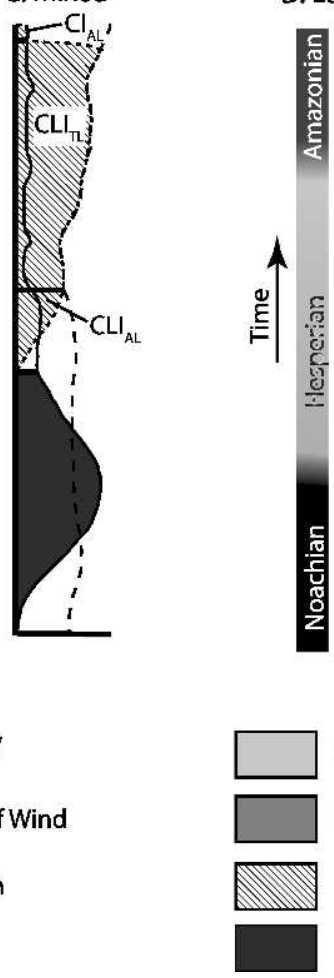

Contemporaneous Influx

Lagged Influx

Contemporaneous \& Lagged Influx

Stored Sediment

FIG. 3.- Sediment state diagrams for Earth (A-C) and Mars (D-F), in which sediment generation, transport capacity of the wind, and sediment availability (all in volumes) are simultaneously plotted against time to yield all possible dune-field configurations. (A) Dune field sourced by contemporaneous sediment influx $(\mathrm{CI})$, which is limited by sediment availability $\left(\mathrm{CI}_{\mathrm{AL}}\right)$ or the transport capacity of the wind $\left(\mathrm{CI} \mathrm{IL}_{\mathrm{TL}}\right)$. $(\mathrm{B})$ Dune field sourced from previously stored sediment (lagged influx, LI). Dune-field construction may be availability-limited (LI $\mathrm{LL}_{\mathrm{AL}}$ ) or transportlimited $\left(\mathrm{LI}_{\mathrm{TL}}\right)$. (C) Dune field sourced from both previously stored sediment and contemporaneous influx (CLI) and may be availabilitylimited $\left(\mathrm{CLI}_{\mathrm{AL}}\right)$ or transport-limited $\left(\mathrm{CLI}_{\mathrm{TL}}\right)$. (D) Earth analog for Mars, in which dune fields are contemporaneous or somewhat lagged in time with enhanced Noachian sediment generation. (E) Slow cumulative model, in which Noachian dune-field construction is followed by continued, slow dune-field construction, which is strongly availability-limited owing to the slow rate of sediment production. (F) Episodic model for dune-field construction incorporating Noachian construction and subsequent slow sediment production, but this model postulates episodic enhanced sediment production and periodic sediment availability and sand-transporting wind events. The results are episodes of dune-field construction of various types. See Kocurek and Lancaster (1999) for additional details on diagram construction and term definitions.

timescales that are not necessarily correlated (Fig. 3F). For example, sediment generation for intercrater dune fields is initiated by shortlived, local impact events (i.e., Fenton 2005). On a longer timescale, the eolian Planum Boreum cavi unit may have arisen through reworking of older Planum Boreum units (Rupes Tenuis and Scandia unit), which were emplaced as distal deposits of outflow channels in which large volumes of sediment were deposited on the northern plains during the Hesperian (Tanaka et al. 2010). Unlike Earth, where sandtransporting winds are taken as a "given" (Fig. 3A-C), in the Martian "episodic" model sand-transporting winds represent episodic events, as gauged by the infrequency of sand-transporting winds. Similarly, sediment availability may be episodic because during much of Martian history frost (both $\mathrm{H}_{2} \mathrm{O}$ and $\mathrm{CO}_{2}$ ) and permafrost may have limited the ability of the wind to entrain sediment (c.f., Schatz et al. 2006, Schorghofer and Edgett 2006, Bourke et al. 2008, Feldman et al. 2008, Fenton and Hayward 2010). Where ice is a control on sediment availability, the potential for grain entrainment may vary by seasons or Milankovitch cycles. Dune-field construction is episodic because it relies upon the favorable coincidence of all three components of sediment state.

In another significant departure from Earth, planetary resurfacing on Mars probably includes direct eolian deflation of indurated dunes and sedimentary strata. Earth-style cementation (i.e., lithification), which typically occurs in the subsurface with the passage of large volumes of pore waters, must be very restricted on Mars because of the waterlimited state. Rather, Martian strata are probably poorly lithified, and ice/frost cementation is widespread (e.g., Schatz et al. 2006, Bandfield and Feldman 2008, Bourke et al. 2008, Byrne et al. 2009). Given ice cementation, sediment generation (recycling) would occur with sublimation driven by climatic cycles at a variety of temporal scales (i.e., daily to Milankovitch). Probable examples include the deflation of indurated dunes (e.g., Edgett and Malin 2000) and, in particular, the wholesale reworking of the Planum Boreum cavi unit in the North Polar Region to source the Olympia Undae Dune Field (Byrne and Murray 2002, Tanaka et al. 2008). 


\section{Questions}

Weathering, erosion, and sediment production are very limited on the current Martian surface, yet large volumes of sediment have been generated on Mars. The fundamental questions are (1) by what processes were these sediments generated, and (2) how have these processes varied over time? What is the relative balance between physical and chemical weathering in sediment production? What proportion of eolian sediments can be accredited to Noachian vs. later Hesperian and Amazonian processes? Is sediment abundant on the Martian surface simply because it is rarely removed? At what rates and by what processes are indurated dunes and sedimentary strata recycled on the planet?

\section{GRAIN TRANSPORT (GRAIN-FLUID INTERACTIONS)}

\section{Earth}

Eolian sediment-transport systems on Earth develop wherever there is a sediment source, this sediment is available for entrainment by the wind, and wind speeds occur that are capable of sand transport. The friction speed $\left(\mathrm{u}_{*}\right)$ necessary to initiate movement (i.e., static or fluid threshold) is only $\sim 0.15$ to $0.25 \mathrm{~m} / \mathrm{s}$ for quartz grains 0.1 to $0.3 \mathrm{~mm}$ in diameter, which form the bulk of sand dunes on Earth (Bagnold 1941; p. 88). Using grain roughness only, wind speeds required to initiate grain movement are only 4.7 to $7.2 \mathrm{~m} / \mathrm{s}$ at $1 \mathrm{~m}$ above the surface (i.e., a 10-16-mph breeze). For continued saltation (i.e., dynamic or impact threshold), $\mathrm{u} *$ falls to 0.12 to $0.20 \mathrm{~m} / \mathrm{s}$, or a wind speed of 2.8 to $4.0 \mathrm{~m} / \mathrm{s}$ at $1 \mathrm{~m}$ above the surface. Most dune sand moves by saltation, with the coarser fraction traveling in surface creep via impacts from saltating grains.

Sand transport occurs as blowing sand, or as ripples, and then as dunes with growing surface availability of sand. Dunes, therefore, fundamentally represent packages of sand in transport, and a dune-field constructional event requires only sufficient available sand and transporting winds. Measured dune migration rates and interpreted rates from the rock record based upon annual cycles (e.g., Hunter and Rubin 1983) range from less than a meter to a few meters per year for large dunes to tens of meters per year for small dunes. Because the volume of sand transported by the wind increases as a cubic function of friction speed, significant dune activity occurs during less-common high-energy events.

Wilson (1973) was first to recognize that the eolian sedimenttransport system on Earth could be desert-wide, with major dune fields typically forming within areas of wind deceleration, such as in topographic basins, where the flow expands vertically. Because of the potential long-distance transport of sand, it is commonly difficult to identify the source of eolian dune fields in even modern systems.

\section{Mars}

Compared to Earth, the basic boundary conditions on Mars that govern eolian transport are a lower surface gravity $\left(3.7 \mathrm{~m} / \mathrm{s}^{2}\right.$ on Mars vs. $9.8 \mathrm{~m} / \mathrm{s}^{2}$ on Earth) and a much lower atmospheric density $(0.02 \mathrm{~kg} /$ $\mathrm{m}^{3}$ on Mars vs. $1.23 \mathrm{~kg} / \mathrm{m}^{3}$ on Earth). Combined, these boundary conditions indicate that the initiation of sand transport by the wind is much more difficult than on Earth, but a continuation of transport occurs more readily. The most common grain mineralogy on Mars is basalt, which is somewhat denser than quartz, the most common eolian grain on Earth $\left(3.0 \mathrm{~g} / \mathrm{cm}^{3}\right.$ for basalt vs. $2.65 \mathrm{~g} / \mathrm{cm}^{3}$ for quartz). Thermal inertia data from space-borne imagery of Mars indicates that Martian dunes have an average grain size that is coarser (medium- to coarsegrained sand) than on Earth (Edgett and Christensen 1991, Presley and Christensen 1997). Limited surface observations (e.g., Gusev Crater by
Greeley et al. [2006] and Sullivan et al. [2008]; Meridiani Planum by Jerolmack et al. [2006]) indicate eolian sands that are similar in size or slightly finer than those on Earth.

Wind tunnel experiments (e.g., Greeley et al. 1980, Iverson and White 1982) indicate that the threshold (i.e., fluid or static) friction speed to initiate sand movement on Mars is about an order of magnitude greater than that on Earth (i.e., $2.2 \mathrm{~m} / \mathrm{s}$ on Mars vs. $0.22 \mathrm{~m} / \mathrm{s}$ on Earth for 0.2-mm grains in the Greeley et al. experiments). This is a direct result of the low atmospheric density, which reduces the fluid drag on grains. Using relationships derived from Iverson and White (1982), Jerolmack et al. (2006) determined a $\mathrm{u}_{*}$ of 2.5 to $3.5 \mathrm{~m} / \mathrm{s}$ for formation of wind ripples traversed by Opportunity on Meridiani Planum. These ripples consist of very coarse $(1.3-\mathrm{mm})$, hematitic $\left(\mathrm{p}_{\mathrm{s}}=\right.$ $\left.4.1 \mathrm{~g} / \mathrm{cm}^{3}\right)$ sand crests and fine-grained $(\sim 0.05-0.2-\mathrm{mm})$ basaltic sand interiors. Accounting for surface roughness, formative winds at $1 \mathrm{~m}$ above this surface ranged from 49 to $70 \mathrm{~m} / \mathrm{s}$, or Earth hurricane category 3 to 4 on the Saffir-Simpson scale.

The lower gravity on Mars and a lower vertical fluid drag (caused by the lesser atmospheric density), however, cause a much larger hysteresis on Mars vs. Earth between the threshold and dynamic friction speeds (Claudin and Andreotti 2006, Kok 2010). Once initiated, saltation may continue at wind speeds an order of magnitude less than required to initiate it (Kok 2010), and transport itself has been suggested to be more energetic than on Earth (Almeida et al. 2008).

Given the potential for eolian transport, the frequency of transport and the conditions required for transport to occur are not clear. The Martian atmosphere is clearly dynamic, dust storms are common (e.g., Cantor et al. 2006), small dunes appear to have been deflated (Bourke et al. 2008), sand deposits have been modified at Gusev Crater (Sullivan et al. 2008), complex wind regimes are evident (e.g., Tsoar et al. 1979, Greeley et al. 2000, Ewing et al. 2010, Silvestro et al. 2010a), and sand has accumulated on the decks of the rover Spirit (Greeley et al. 2006). Most notably, Silvestro et al. (2010b) report $\sim 1.7 \mathrm{~m}$ of migration within 4 months for ripples on the stoss slope of a barchan dune in Nili Patera. In contrast, Golombek et al. (2010) show that no migration has occurred in hundreds of thousands of years for a field of ripples at Meridiani Planum, and calculated dune migration rates under present conditions are orders of magnitude slower than on Earth (Claudin and Andreotti 2006, Parteli and Herrmann 2007). Currently, an understanding of the frequency of sand transport on Mars is hindered by both the limited time-series of dune images needed to determine morphological change and the unknown ages of eolian features globally.

In addition, the nature of the sand-transporting winds is not known. Although the occurrence of major dune fields appears broadly consistent with global wind patterns (Anderson et al. 1999), and although Hayward et al. (2007) found a general agreement between crestline orientations and predicted GCM wind patterns, more localized winds may well be more significant in sand transport. Extensive documentation of wind-formed surface features in Gusev Crater (as seen in Spirit images) shows the dominance of topographymodified surface winds (Greeley et al. 2006). The short radiative timescales and lower inertia of the thin $\mathrm{CO}_{2}$ Martian atmosphere make nighttime katabatic winds stronger than on Earth (Spiga 2011), and modeling argues for these denser, shallow flows emanating from uplands (Maria et al. 2006). Katabatic winds are paramount in the formation of eolian features on the polar ice caps (e.g., Howard 2000) and are thought to be a significant sand-transporting wind in the Olympia Undae Dune Field (Ewing et al. 2010). As with a determination of wind frequency, the lack of long-term data hinders a determination of what components of the wind system transport sand as well as determination of the conditions required for these transport events to occur.

Sediment availability on the surfaces poses an additional issue that must be considered in evaluating eolian transport on Mars 
Calculations of sand transport based upon shear stress assume that sediment is available on the surface for transport. As noted above, surface stabilization by frost and permafrost is probably widespread and a primary cause for current dune stability, especially in the higher latitudes (Schatz et al. 2006, Bourke et al. 2008, Feldman et al. 2008, Ewing et al. 2010, Fenton and Hayward 2010). Surface stabilization would not only restrict actual sediment flux but also cause potential sand-transporting winds to be undersaturated and erosional, manifested by common surface features such as grooves and yardangs.

Given the current infrequency of sand transport on Mars, it is remarkable that, as first recognized by Breed et al. (1979), most dunes appear in terminal constructional settings such as basins, typically with no obvious sand-transport paths. This includes crater basins (e.g., Fenton et al. 2003, Fenton 2005, Hayward et al. 2007), valleys and troughs (Bourke et al. 2004), and the large north polar topographic basin (Tanaka et al. 2008). One possibility is that most dune fields are derived from in-basin sources and that transport paths are short (Fenton et al. 2003, Fenton 2005, Fenton and Hayward 2010). The second possibility is that most dune fields were emplaced during distant times and their sources and transport corridors have been long erased. Silvestro et al. (2010a) demonstrated sand-transport corridors connecting dune fields over a scale of tens of kilometers, but no long-distance transport comparable to that of Earth has yet been documented.

\section{Questions}

There is a dichotomy on Mars between the current apparent infrequency of sand transport and the commonness of eolian geomorphic and stratigraphic features, especially the occurrence of dune fields within terminal basins. When does eolian transport occur? Are eolian features on Mars largely the product of rare high-energy events? Are transport events associated with specific seasons, global conditions, or portions of Milankovitch cycles? Has the frequency of sand transport changed over Martian history? Are dune fields relicts of a distant, denser atmosphere? What components of the wind system drive sand transport? Are these winds part of the global circulation, local orographic winds, or shallow katabatic winds from ice caps and highlands? Do factors that increase flow density (i.e., very cold katabatic winds) significantly increase transport capacity? Is current dune stability primarily a function of the infrequency of high winds or a result of surface stabilization? Are dune fields on Mars primarily locally derived from in-basin sources, or has evidence for past longdistance transport corridors been lost?

\section{DUNE DEVELOPMENT (DUNE-FLOW INTERACTIONS)}

\section{Earth}

As is the case for all bedforms, eolian dunes develop through interactions between the flow field and the sediment bed (Fig. 4). Within these complex-system interactions, the "primary" flow (i.e., the flow before the bedforms) becomes slaved to the emergent bedform topography (and not the other way around) to produce a characteristic "secondary" flow over the bedforms. This characteristic secondary flow differs in speed, direction, shear stress, and level of turbulence from the primary flow as a function of position on the bedform (for eolian dunes, see Frank and Kocurek [1996a, 1996b] and Walker and Nickling [2003]). The most basic flow field over dunes consists of flow acceleration and erosion on the upstream or stoss slope and flow deceleration and deposition on the downstream or lee slope. The resultant dune migration causes the formation of a set of cross-strata, which is a record of lee-face deposition over time with dune migration.
Dune Development $\rightarrow$ Sets of Cross-Strata

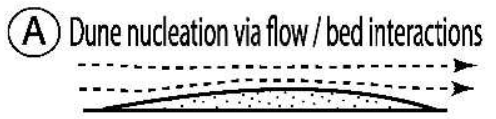

(B) Development of secondary flow over dune and stratification types

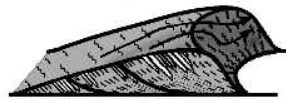

\section{(C) Crestline orientation and dune type determined by wind regime}

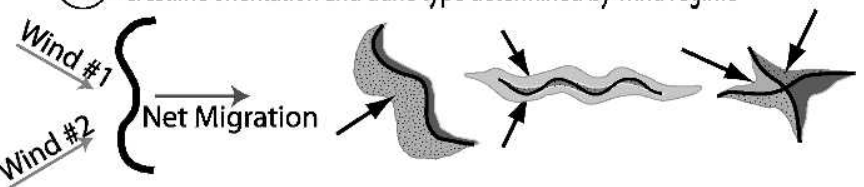

(D) Evolution of dune-field pattern by dune-dune interactions

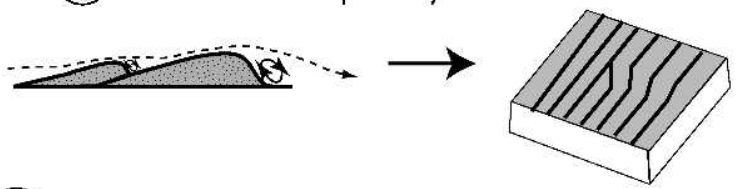

(E) Set of cross-strata \& bounding surfaces develop with dune migration

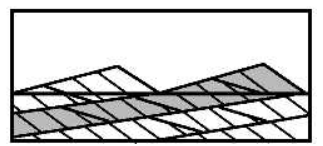

FIG. 4.- Schematic representation of stages from dune development through generation of sets of cross-strata. (A) Dune nucleation through flow and sediment bed interactions. (B) Development of secondary flow over emergent dune topography with resultant surface processes and stratification types. (C) Crestline orientation as a function of the wind regime. (D) Field-scale pattern emerges and continues to evolve through dune-dune interactions. (E) Generation of sets of cross-strata with bounding surfaces as dunes migrate and accumulations form. Stages A through D occur within the eolian transport system of Fig. 1.

The three-dimensional geometry of a set of cross-strata is a function of dune shape and behavior over time (e.g., Rubin 1987).

On Earth, dune development commonly occurs within a wind regime that varies in both direction and speed, typically as seasonal cycles (Fig. 4). Because of this boundary condition, as eolian dunes grow and become too large to reorient with changing wind directions, the crestline assumes an orientation that is as perpendicular as possible to all sand-transporting wind directions (i.e., gross bedform-normal transport of Rubin and Hunter [1987]). It is this variability in wind directions that yields the diversity of "simple" dunes on Earth (e.g., crescentic, linear, star).

Because dune crestlines are not straight and because the overall crest orientation is the gross bedform-normal orientation, a given primary wind direction may be transverse, oblique, or longitudinal to specific segments of the crestline, as defined by the incidence angle, which is the angle between a wind direction and the orientation of a segment of crestline (Fig. 5). Characteristic secondary flow conditions develop for each of these categories of incidence angles (Sweet and Kocurek 1990, Walker and Nickling 2002). Each characteristic secondary flow 


\section{Lee-Face Secondary Flow \& Stratification Types}

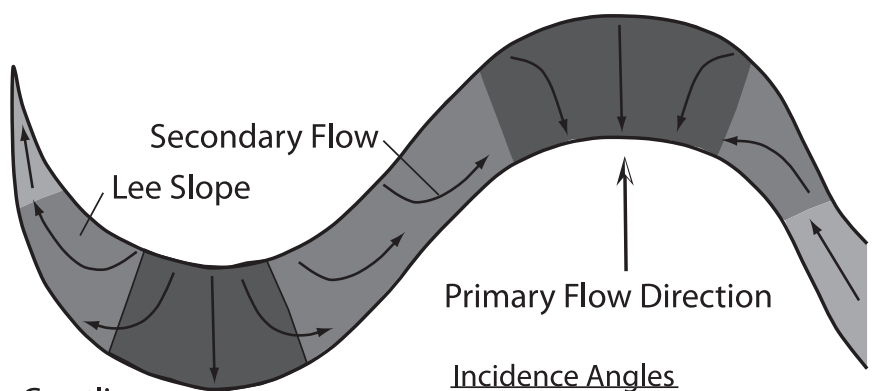

Crestline-

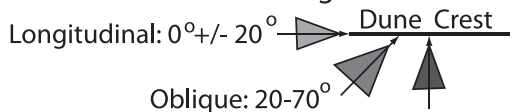

Transverse: $90^{\circ}+/-20^{\circ}$

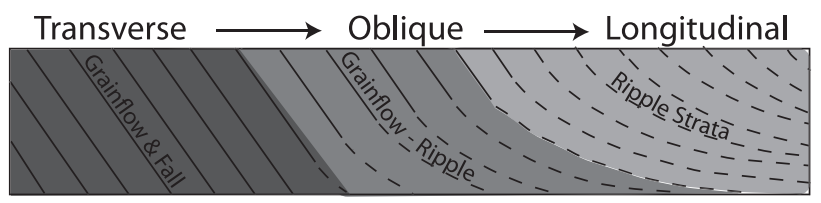

FIG. 5.- Idealized secondary flow over the lee face of a curved dune crestline, with characteristic dune stratification. Local incidence angles between the primary flow direction and the crest segment determine the lee secondary flow. In turn, the secondary flow gives rise to surface processes and their stratification. Other stratification types occur (see Kocurek 1991), primarily reflecting temporal change (e.g., annual cycles that yield transverse to oblique repetitive couplets).

condition, in turn, gives rise to surface processes that result in a specific configuration of stratification types with deposition (Kocurek 1991). The basic stratification types from Hunter (1977) are (1) wind-ripple laminae, which occur with traction transport; (2) grainfall strata formed by grains blown past the dune brink to settle under the influence of gravity and lee turbulence (Nickling et al. 2002); and (3) grainflow strata that form by the gravity-driven avalanching of grainfall deposits once these reach the angle of initial yield. The spatial (i.e., along the crestline) and temporal (in the migration direction) configuration of stratification types within a set of cross-strata is the primary tool in reconstructing paleo-flow conditions (e.g., Hunter and Rubin 1983, Kocurek et al. 1991b).

In addition to the gross geometry of sets of cross-strata and distribution of stratification types within a set, bounding surfaces are the third component in reconstructing dunes and flow conditions (Fig. 6 ). Bounding surfaces occur with the migration of bedforms (Brookfield 1977) and consist of (1) reactivation surfaces within a set of crossstrata that form with any erosional reconfiguration of the lee face during migration, (2) superposition surfaces that form with the migration of superimposed dunes over the larger host bedform, and (3) interdune surfaces that separate sets or co-sets of cross-strata (see discussion in Kocurek [1996]). At the regional or basin scale, yet more extensive bounding surfaces cap entire eolian sequences ("super surfaces" of Kocurek [1988]) and may arise for a variety of reasons, including the onset of a more humid climate, in which dunes are stabilized by vegetation, development of an armoring lag surface on the trailing margin of a migrating dune field, and exhaustion of the sediment supply with deflation to the capillary fringe of the water table.

The large body of works on eolian units from the stratigraphic record on Earth shows that overall boundary conditions for dune development on Earth have been similar during the entire Phanerozoic. Rephrased, the range of grain sizes, stratification types, architecture created by dune migration, and creation of regional bounding surfaces can be interpreted by observable processes, ranges, and rates. The potential to detect differences in earlier Earth history is limited by the rarity of

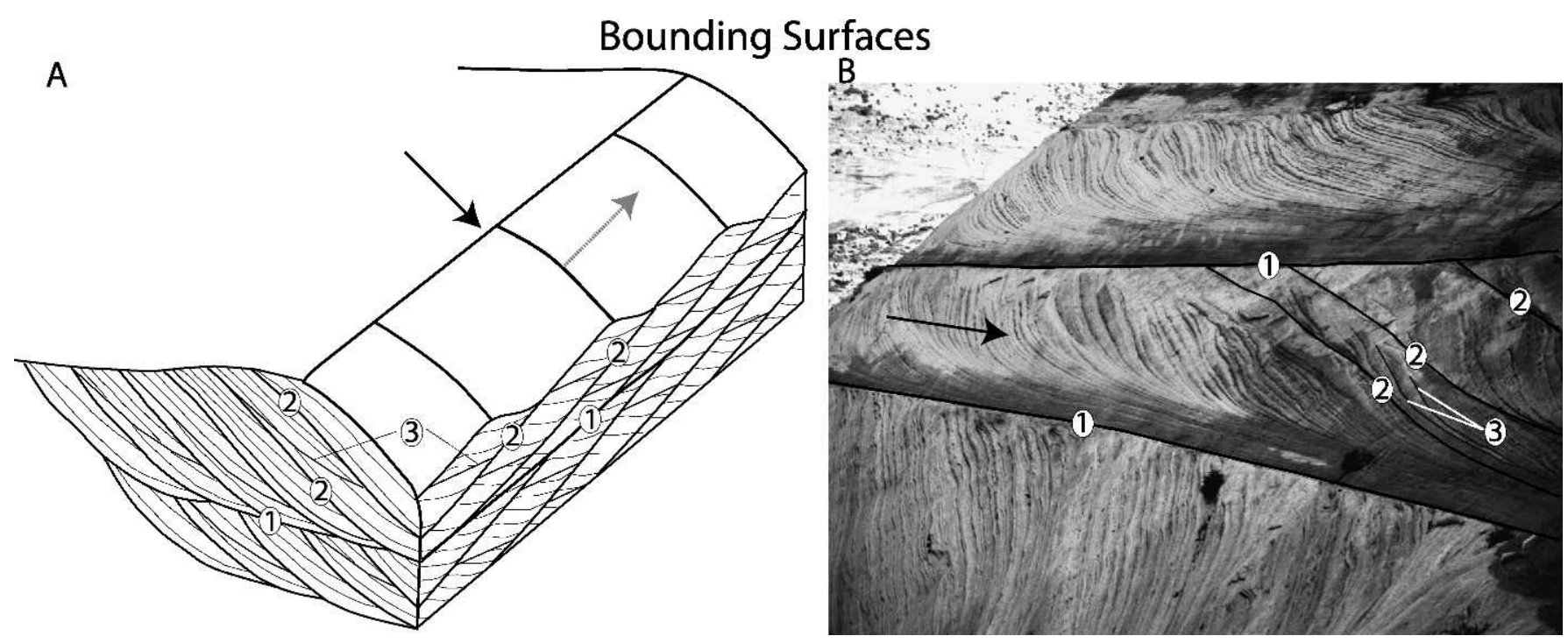

FIG. 6.-Generation of bounding surfaces with dune migration. (A) Diagrammatic compound dune with lee superimposed dunes migrating alongslope the larger host bedform; migration directions shown by arrows. This configuration is the most common compound dune type. Drawn and modified from computer-generated cross-strata in Rubin (1987). (B) Compound cross-strata in Jurassic Entrada Sandstone near Vernal, Utah, interpreted as representing a compound bedform. Labeled set has a maximum thickness of $2 \mathrm{~m}$. Arrow shows migration direction of the main bedform; superimposed bedforms migrated into the page. Some bounding surfaces labeled in A and B: (1) interdune surface, (2) superposition surfaces, (3) reactivation surfaces, as described in the text. 
A

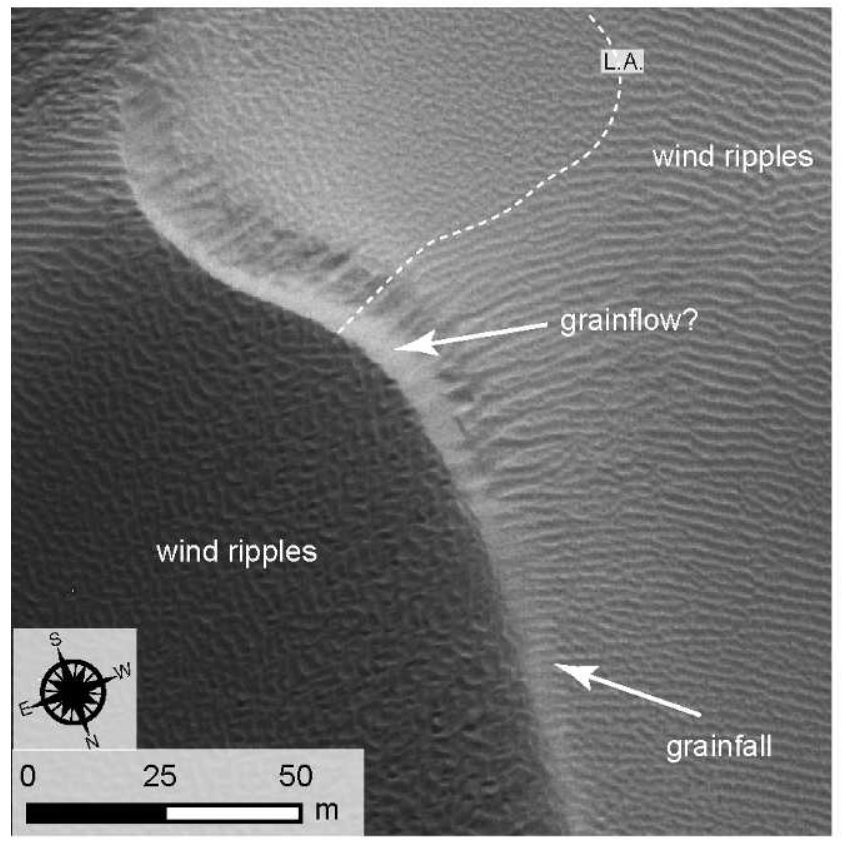

B

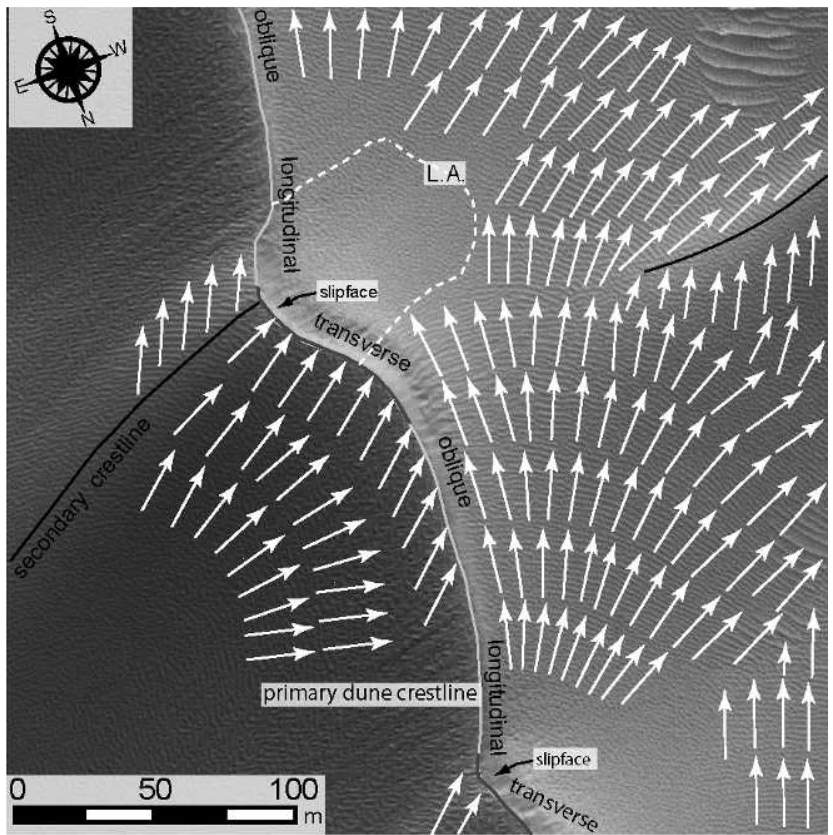

FIG. 7.- Secondary flow and surface processes on a dune segment in Olympia Undae. (A) Portion of crestline in (B) showing surface features arising from the dune-modified secondary airflow and line of attachment (L.A.) that defines the lee separation cell. Note poor ripple development within the separation cell. (B) Secondary flow-field based upon wind ripple orientations; white arrows indicate transport direction. Modified primary flow up the stoss slope is from the northeast. Range of incidence angles (transverse, oblique, longitudinal) defined by local crest orientation to the primary wind. Lee secondary flow field show deflected along-slope transport, separation cell, flow recovery leeward, and deflection along a yet-leeward dune spur. Note that the transverse portions of the crestline are coincident with grainflow, with a widening wedge of grainfall extending from the oblique segment into the transverse segment. From Ewing et al. (2010).

surviving eolian strata. Eolian strata on Earth older than $1.8 \mathrm{Ga}$ (Hesperian-Amazonian boundary on Mars) are rare (Eriksson and Simpson 1998), meaning that many of the events and processes that affected eolian strata on Mars pre-date the earliest eolian records on Earth.

\section{Mars}

Based upon the Mars Global Digital Dune Database (Hayward et al. 2007) and earlier views from Mariner and Viking images (Greeley et al. 1992), most dunes on Mars are some variety of crescentic dune (i.e., crescentic ridges and barchans, the latter of which represent a lower sand availability). Other dune types have been recognized, including linear and star dunes (e.g., Edgett and Blumberg 1994, Lee and Thomas 1995), a variety of dune features associated with topography (Bourke et al. 2004), and some dune forms that are more enigmatic in classification (e.g., transverse eolian ridges; Zimbelman 2010). The overwhelming dominance of crescentic dunes on Mars, however, contrasts with the much greater variety of dunes on Earth and the commonality of linear dunes. Because crescentic dunes form in a more unidirectional wind regime than linear dunes, which require an obtuse bidirectional wind, and star dunes, which can form in multidirectional winds or a bimodal regime where the winds are roughly perpendicular to each other (e.g., Rubin and Hunter 1987, Rubin and Ikeda 1990), the simplest explanation is that the constructive wind regimes on Mars are less complex than on Earth.

Where secondary airflow has been mapped over dunes by the orientation of wind ripples in HiRISE images (Ewing et al. 2010), the spatial distribution of surface processes and the predicted airflow behavior is consistent with Earth examples (Fig. 7). In this Olympia Undea example, lee-slope deflection of the flow occurs with an oblique incidence angle, and a slipface and separation cell occur in the lee of areas with a transverse incidence angle.

The most detailed outcrop analysis of eolian cross-strata on Mars is for the Burns formation, as viewed by Opportunity in the Endurance Crater (Grotzinger et al. 2005) and in the Erebus Crater (Metz et al. 2009). Stratification types, especially the distinctive wind-ripple laminae, are clearly visible, as are reactivation surfaces and an interpreted super bounding surface (Wellington). The presence of reactivation surfaces and the dominance of wind-ripple laminae indicate that the winds were not unidirectional.

\section{Questions}

In complex-system hierarchy theory (e.g., Werner 2003), lower-level variables become "slaved" to emergent higher-level emergent behavior as the system evolves (Fig. 1). For the Martian eolian transport system, although there are significant differences from Earth at the fluid-grain level, these may become subordinate to emergent dune topography at the higher flow-bedform level. Martian dunes and dune dynamics would, therefore, be very similar to those of Earth, although differences may exist because of local boundary conditions (i.e., the shape of grainflow may differ as a result of unequal sublimation over the surface). The promise, therefore, is that dune geomorphic and stratigraphic features can be interpreted by principles evident on Earth. What, then, do current dune fields of different ages and latitudes 
A

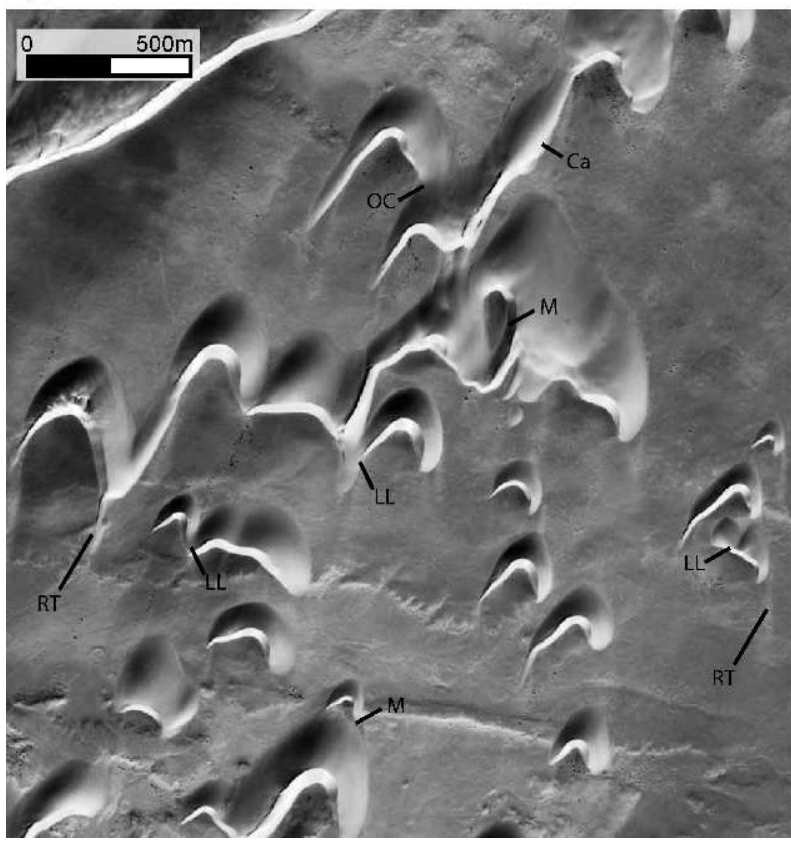

B

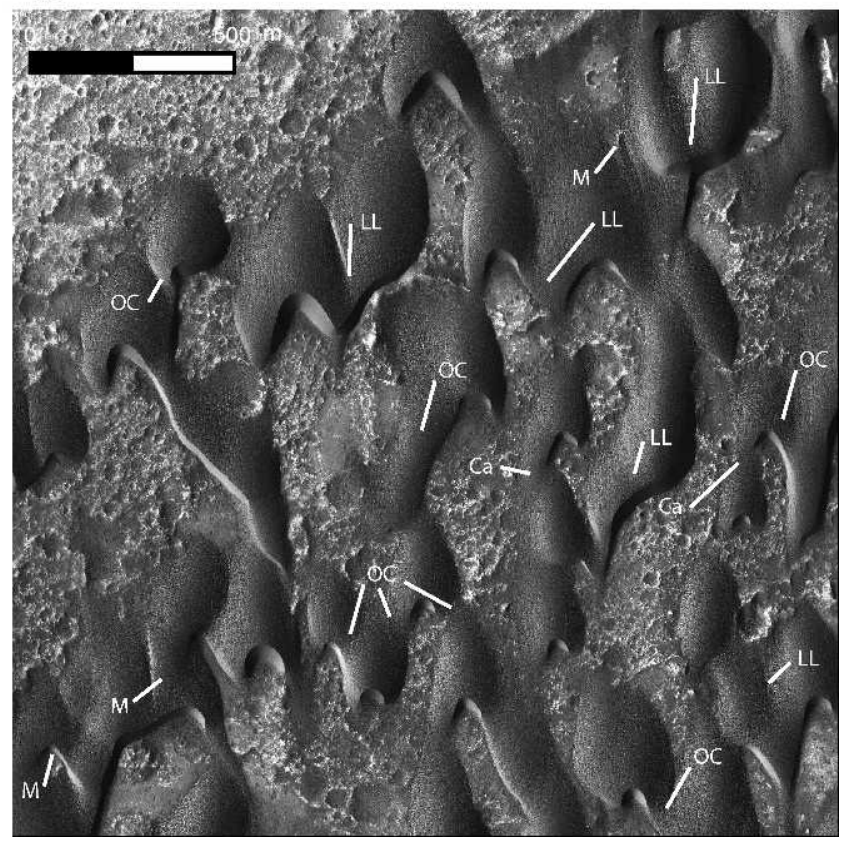

FIG. 8.-Similar eolian dune interactions in the (A) Western Sahara and (B) Herschel Crater, Mars (HiRISE PSP_002860_1560). Dune-dune interactions are the dynamics by which the dune field organizes and evolves. Interactions include constructive interactions of merging (M), lateral linking (LL), and remote transfer of sediment (RT); neutral interactions of off-center collision (OC) and regenerative interactions of calving $(\mathrm{Ca})$.

indicate for temporal and zonal conditions on Mars? Does the Martian eolian stratigraphic record house a chronology of environmental change on Mars? Does the Martian eolian record show the environmental shift from the Noachian into Hesperian and Amazonian times?

\section{DUNE-FIELD PATTERN DEVELOPMENT (DUNE-DUNE INTERACTIONS)}

\section{Earth}

Dunes on Earth, as well as on Mars, form some of the most striking patterns in nature (Fig. 8A, B). As with most other bedform patterns in air and water, these dune patterns are thought to emerge from a nonpatterned state through self-organization-that is, through the interactions between the bedforms themselves (Werner 1995, 1999). Bedform interactions occur as bedforms or their crestal terminations (defects) approach each other or actually collide. Dune and other bedform interactions have been documented in a range of settings (see review in Kocurek et al. [2010]), and pattern emergence and evolution as a function of bedform interactions have been explored in models (e.g., Forrest and Haff 1992, Landry and Werner 1994) and with natural bedforms (e.g., Hersen and Douady 2005, Elbelrhiti et al. 2008, Ewing and Kocurek 2010a).

Although the specific dynamics of bedform interactions differ by bedform type (ripple vs. dune) and fluid (air vs. water), types of bedform interactions are geomorphically similar across scales of bedforms and fluids and can be classified based on the portions of the bedforms that are interacting and the impact of the interactions upon pattern development (Kocurek et al. 2010). Interactions occur between whole bedforms, between bedforms and defects, between defects alone, and as exchanges of sediment between bedforms where the bedforms remain apart. The spectrum of bedform interactions, in turn, is constructive, regenerative, or neutral with respect to pattern development. Constructive interactions (e.g., merging of bedforms, lateral linking of terminations, cannibalization) yield fewer bedforms than are interacting, and the field-scale pattern evolves toward fewer, larger, more widely spaced bedforms with longer crestlines. Regenerative interactions (e.g., bedform splitting, calving, defect creation as bedform crests break laterally) yield more bedforms than are interacting and result in a decrease in spacing and crest lengths. Other bedform interactions introduce considerable dynamics into the bedform pattern but may be largely neutral in terms of pattern construction (i.e., yielding the same number of dunes as are interacting). These interactions include collisions between bedforms (bedform repulsion) and defect-bedform collisions (defect repulsion), by which a new bedform or segment of one of the colliding bedforms is ejected during the collision process.

The diversity in bedform patterns (i.e., no two patterns on Earth are exactly the same), however, is thought to arise because of the boundary conditions in which the bedform interactions occur (Ewing and Kocurek 2010b, Kocurek et al. 2010). Boundary conditions are most different between fluids (air vs. water) and bedform types (ripple vs. dune), but field-scale patterns are never exactly the same, even among the same type of bedforms. For eolian dunes, no two dune-field patterns are exactly alike, and this is thought to reflect the fact that field-scale boundary conditions are never exactly the same. Typical eolian dune-field boundary conditions include the intensity/durations of wind directions, sediment availability, antecedent topography, the geometry of the sediment source (i.e., point, line, plane), and areal shape and size of the basin housing the dune field (Ewing and Kocurek 2010b).

Although still in its infancy, an understanding of how specific dunefield patterns develop by dune interactions operating within a set of 


\section{Accumulation of Aeolian Strata}
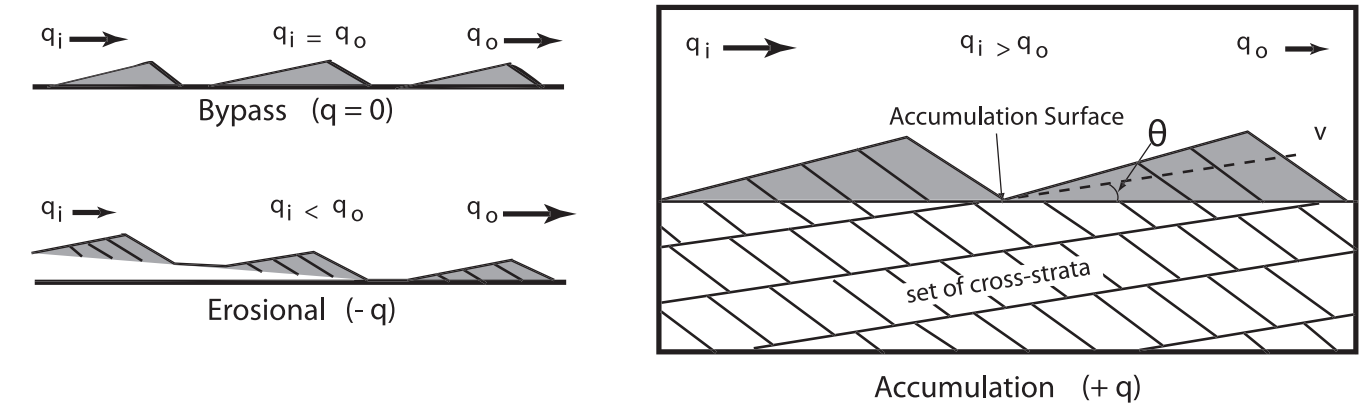

Accumulation Dynamics in System Types

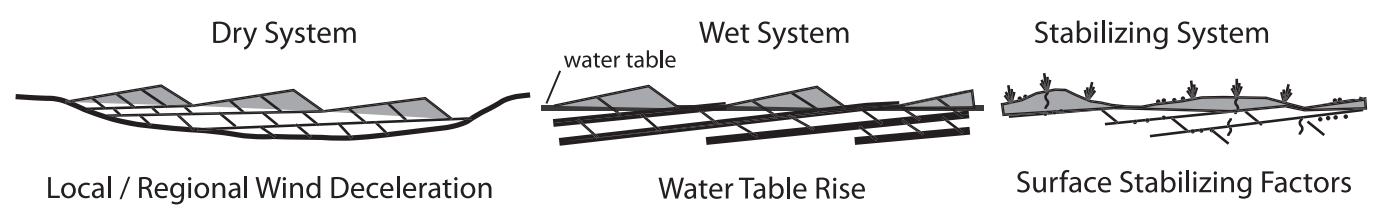

Fig. 9.-Bypass, erosion, and accumulation of eolian strata, as defined by the sediment budget. Accumulation occurs in dry, wet, and stabilizing systems by specific dynamics. See text for discussion.

boundary conditions may have a transformative impact upon interpretations. For example, basin shape and size impacts pattern development by limiting the type and number of dune interactions (Ewing and Kocurek 2010b). Conversely, pattern development and shape may then imply the nature of long-lost source areas and transport corridors. All else being equal, pattern dating is a possibility based upon the degree of pattern construction (Ewing et al. 2006). Unless restricted by some boundary conditions, the general trend in dune-field pattern evolution is constructive (i.e., toward fewer, larger, more widely spaced dunes), with interactions becoming less frequent as dunes migrate more slowly and become more distant from each other. Because any given wind regime produces one dune-field pattern (Kocurek and Ewing 2005), complex patterns, in which simple patterns are superimposed, provide a means for interpreting temporal changes in environmental parameters (e.g., Beveridge et al. 2006, Derickson et al. 2008). Because dune interactions create bounding surfaces and alter the secondary flow over dunes, it should be possible to identify these interactions in ancient eolian strata, thereby providing a new range of interpretation to the deterministic models of Rubin (1987).

\section{Mars}

Dune interactions similar to those on Earth are obvious in highresolution images of Mars (Fig. 8B), but these have been little explored, and there has been only initial use of pattern analysis on Mars (e.g., Bishop 2007, Ewing et al. 2010). Pattern analysis of a portion of the Olympia Undae Dune Field by Ewing et al. (2010) used statistical treatment of pattern parameters (i.e., crest length, spacing, defect density, crest orientations), secondary airflow over the dunes (Fig. 7), and other geomorphic evidence to show that the reticulate pattern is complex and consists of two constructional generations of dunes. The oldest and most organized set of crestlines formed transverse to circumpolar easterly winds, whereas the younger pattern can be shown to have originated with components of the easterly winds and more recent katabatic winds. The antecedent topography of the older dune pattern formed a boundary condition to development of the younger pattern, but the younger pattern is reworking the older pattern by defect creation. Significantly, the degree of pattern development of even the older pattern, while greater than that evident in White Sands, New Mexico ( $\sim 7 \mathrm{ka}$; Langford 2003, Kocurek et al. 2007), is less than that of major dune fields on Earth (e.g., Sahara in Mauritania, Gran Desierto in Mexico, East Taklimakan, Namibia, Arabian Wahiba; see fig. 10 in Ewing et al. [2010]). Because the Olympia Undae Dune Field is much older than any dune pattern on Earth (Tanaka et al. 2008), a very slow rate of pattern development is indicated.

\section{Questions}

Because dune-field pattern evolution through dune-dune interactions occurs high in the hierarchy of the eolian transport system (Fig. 1), pattern development in dune fields on Earth and Mars should be very similar. This implies a robust transfer of our understanding of pattern development on Earth to Mars, and pattern analysis is ideal for planetary studies because it is done remotely from satellite images. Potentially, the relative ages of dune fields on Mars could be determined and the boundary conditions under which these dune fields evolved interpreted. Does the degree of pattern evolution vary spatially over Mars? Does the state of pattern development for crater dune fields correlate with crater age? With crater size? What do dunefield shapes suggest for the nature of source areas? Are there differences in the types and frequencies of dune-dune interactions by latitude or basin size and shape? What can be inferred about wind regime, sediment availability, and other boundary conditions from the dune-field patterns? How is climatic change on Mars reflected in dunefield patterns?

\section{ACCUMULATION OF EOLIAN DEPOSITS}

\section{Earth}

As with other bedforms, most eolian dunes do not build accumulations (i.e., stacks of eolian cross-strata), but rather simply bypass the surface or even scour the surface as they migrate. 


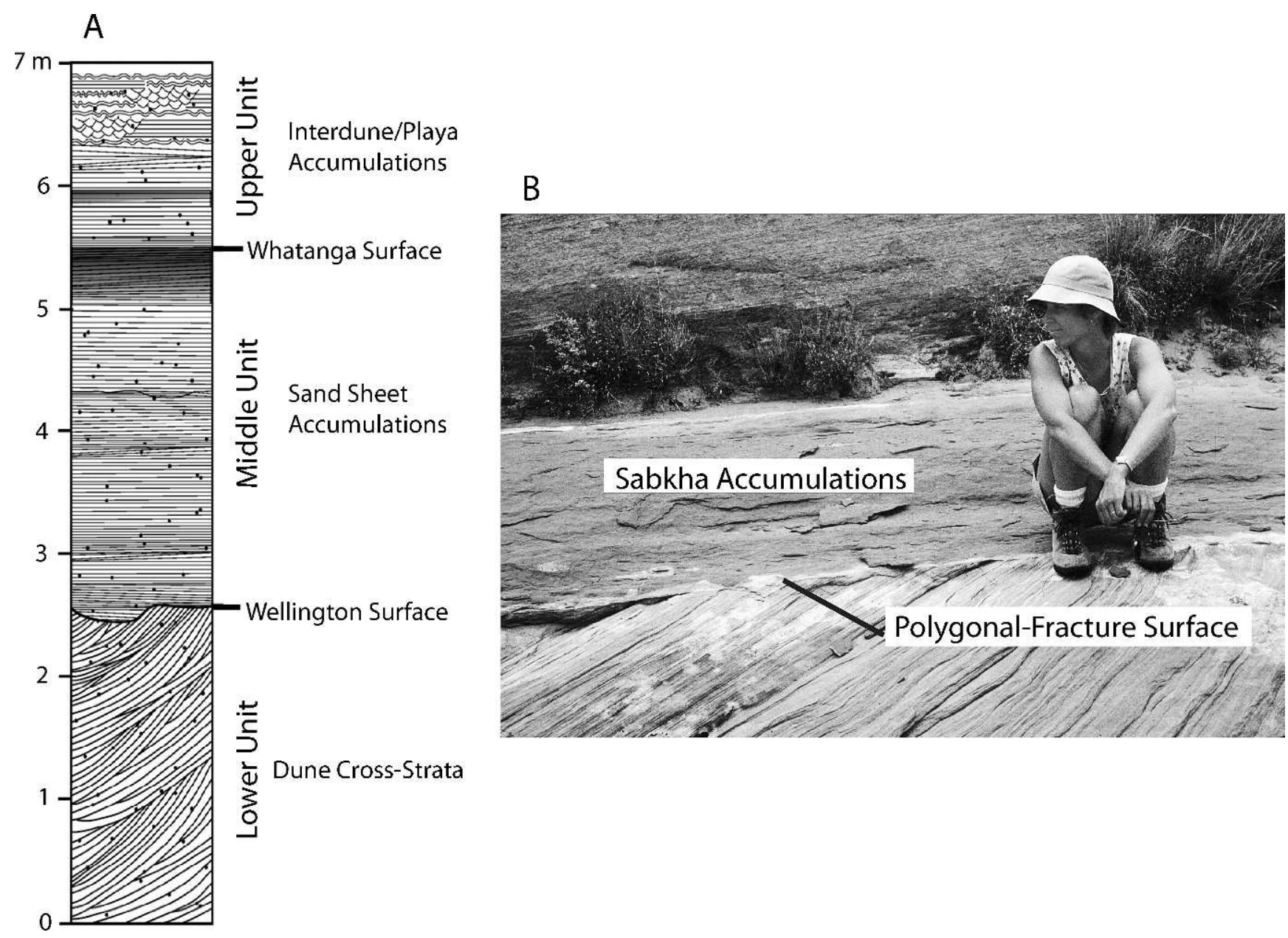

FIg. 10.-Comparison of accumulations in sequences in the Burns formation as seen in Endurance Crater (A) and the Jurassic Page Sandstone, Utah (B). In both cases, interpreted dry-system dune cross-strata underlie water-table-controlled deflation surfaces (Wellington, Mars; polygonally fractured surface, Page). Overlying accumulations are interpreted to have formed with a relative rising water table. Burns section modified from Grotzinger et al. (2005).

Accumulation requires a positive sand budget, in which more sand enters the system than exits, so that the surface over which the dunes are migrating, the accumulation surface, rises over time (Fig. 9). In contrast, bypass along the accumulation surface results in a neutral sand budget, and a negative sand budget characterizes erosional systems in which the accumulation surface falls over time (Kocurek and Havholm 1994). With migrating bedforms, rise of the accumulation surface occurs as bedforms leave behind their lower portions as they migrate (i.e., a set of cross-strata). The relation between bedform migration and behavior of the accumulation surface over time can be characterized by the angle of bedform climb $(\theta)$, defined as $\tan \theta=\mathrm{V}_{\mathrm{y}} /$ $\mathrm{V}_{\mathrm{x}}$, where $\mathrm{V}_{\mathrm{y}}$ is the vertical accumulation rate and $\mathrm{V}_{\mathrm{x}}$ is the bedform migration rate (Brookfield 1977, Rubin and Hunter 1982). Accumulation occurs with a positive angle of climb, whereas the angle of climb is zero for bypass systems and negative for erosional systems. In natural bedform systems, spatial variation in the depth of scour as bedforms migrate complicates the simple image of migrating and climbing bedforms (Paola and Borgman 1991), but the general application of climb theory is robust.

Except in uncommon cases (e.g., dunes buried beneath lava flows), the eolian rock record on Earth is necessarily constructed by dunes that were leaving an accumulation. The causes of accumulation, as well as bypass or erosion, lay with the dynamics of the three basic types of eolian systems: (1) dry, (2) wet, and (3) stabilizing (Kocurek and Havholm 1994, Kocurek 1999) (Fig. 9). Dry eolian systems are those in which aerodynamics alone determine the behavior of the accumulation surface over time. Accumulation most typically occurs in these systems because of a regional deceleration of the wind along pressure gradients or as a result of flow into topographic basins where deceleration occurs with vertical flow expansion (Wilson 1973, Rubin and Hunter 1982). Wet eolian systems are those in which the water table is at or near the surface; accumulation in these systems occurs because of a rise of the capillary fringe over time. These systems are not restricted to areas of decelerating flow. Stabilizing eolian systems are those in which some form of surface stabilization fosters accumulation, such as vegetation that causes wind deceleration.

Modern and ancient eolian systems on Earth have most commonly been dry systems, including the Sahara (c.f., Wilson 1973, Kocurek 1998), the Jurassic Navajo (Kocurek 2003), Jurassic Page (Havholm et al. 1993), and Permian Cedar Mesa (Mountney and Jagger 2004). The Jurassic Entrada may be the best example of a regional wet eolian system (Crabaugh and Kocurek 1993, Crabaugh and Kocurek 1998), 
but wet eolian systems are common in coastal areas (e.g., Padre Island, Texas [Kocurek et al. 1992]; Guerrero Negro, Baja [Fryberger et al. 1990]). The vegetated Thar sand sea may be an example of a regional stabilizing eolian system (Wasson et al. 1983, Singhvi and Kar 2004). Hybrid systems are also common, such as White Sands, New Mexico, where the water table and surface stabilization by gypsum cements are both important controls on the behavior of the accumulation surface over time (Kocurek et al. 2007). In nearly all cases the angle of climb is very low, typically tenths of a degree (e.g., Crabaugh and Kocurek 1993, Mountney and Jagger 2004, Kocurek et al. 2007), because nearly always the rate of dune migration $\left(\mathrm{V}_{\mathrm{x}}\right)$ is much greater than the vertical accumulation rate $\left(\mathrm{V}_{\mathrm{y}}\right)$.

\section{Mars}

Given the water-limited boundary conditions on Mars, dry eolian systems are expected to dominate, and, indeed, most dune fields on the surface occur in craters, troughs, and topographic basins where dry eolian systems are expected to accumulate. Stratigraphic analysis of the Burns formation in Endurance Crater (Grotzinger et al. 2005) shows that the Lower Unit consists of sharp (i.e., dry) bounding surfaces between and within sets of cross-strata and that wet/damp-surface interdune deposits are absent, thus indicating that these dunes accumulated in a dry system (c.f., fig. 19 in Grotzinger et al. [2005]). However, interpreted accumulation of eolian sand sheets (Middle Unit) and interdune/playa deposits (Upper Unit) in an upwardwetting sequence by a rise of groundwater characterizes accumulation in a wet eolian system. The overall unit (fig. 3 in Grotzinger et al. [2005]), in which dry-system dune sets of cross-strata are truncated by a water-table-controlled super surface (Wellington Contact) with overlying sand-sheet and sabkha strata, is identical to many eolian sequences on the Colorado Plateau, such as the Jurassic Page Sandstone (e.g., Havholm et al. 1993) (Fig. 10). For these Earth examples, dry-system dunes accumulated during low-stands, but sand availability was apparently terminated with the onset of marine transgression. Subsequent deflation occurred to the rising water table, which was the inland response to the marine transgression (see Kocurek et al. 2001). Continued rise of the water table allowed for the accumulation of sabkha and related deposits overlying the surface.

Contrasting with the dry/wet system accumulations in the Burns formation are accumulations of the much younger (Amazonian) Planum Boreum cavi unit in the north polar region of Mars. The overall unit architecture consists of preserved dune topography in which (1) stacked dune stoss-slope deposits are bounded by erosional surfaces or surfaces showing minimal permafrost development, as manifested by polygonal fractures, (2) down-lapping lee-face deposits are bounded by surfaces of pronounced permafrost polygonal fractures, and (3) interdune areas show the amalgamation of pronounced permafrost surfaces and ice deposits (Fig. 11). This architecture argues for cycles of dune reactivation and stabilization by freezing. During reactivation stoss slopes were deflated, and lee deposition occurred as downlapping, progradational wedges that tapered onto the interdune floors. During stabilization, the entire dune likely developed a permafrost surface, and wind-blown ice accumulated in interdune hollows. Only the stoss slopes show evidence of deflation; permafrost surfaces appear largely undisturbed on the lee slopes and within interdune hollows. Because dune topography was preserved during stabilization, it served as the antecedent boundary condition during subsequent reactivation such that renewed deposition conformed to the existing dune topography. Remnant dune topography is carried upward through the cavi unit, resulting in exceptionally high angles of bedform climb. Because accumulation of dune strata occurred through freezing, the Cavi dune field is interpreted as a stabilizing system, analogous to Earth systems, within which the most common stabilizing agent is vegetation.

\section{Questions}

The causes of accumulation of eolian strata can be understood by the dynamics that characterize the three basic eolian system types (dry, wet, stabilizing). Planetary boundary conditions dictate the form these dynamics take within these systems. The dynamics of dry eolian systems appear to be readily transferable from Earth to Mars. The dynamics of stabilizing systems may be best manifested on Mars through intergranular freezing and permafrost development. Documentation of wet eolian systems is strong evidence for sustained nearsurface groundwater on Mars. Can the causes of eolian accumulation be recognized on Mars, and have these changed through time? Do these change by latitude? Is accumulation of eolian strata currently occurring in craters and other basins? Is accumulation itself cyclic on Mars?

\section{PRESERVATION OF EOLIAN ACCUMULATIONS}

\section{Earth}

The boundary conditions that cause accumulation of eolian strata on Earth are not entirely the same as those that cause preservation of the accumulations (i.e., incorporation into the rock record). For example, some dune fields of the western Sahara have built significant accumulations, but these rest upon Precambrian basement and have little preservation potential (e.g., Kocurek et al. 1991a). The accumulations within Chott Rharsa in Tunisia, although occupying a foreland topographic basin with a surface elevation below sea level, are in a current state of deflation (Blum et al. 1998). Most eolian accumulations preserved in the rock record on Earth have occurred (1) in subsiding basins where the continued addition of sediment has buried the eolian accumulations, (2) in inland basins that experienced a sustained absolute or relative rise in the water table, or (3) as dune fields adjacent to marine bodies in which transgressions resulted in a rise of the continental water table and/or the eolian accumulations themselves were marine transgressed (Fig. 12; Kocurek and Havholm 1994, Kocurek 1999). For example, the Jurassic sand seas of the Colorado Plateau (Navajo, Temple Cap, Page, Entrada) were all flanked to the west by marine environments, and the eolian record is an eastward back-stepping of vertically stacked eolian units overlain by transgressive marine units within a subsiding foreland basin (see fig. 11.7 in Kocurek [1999]). At the formation level, the water-tablecontrolled deflation surfaces in the Page Sandstone (described above; Fig. 10) all correspond to flood surfaces within the equivalent marine/ sabkha Carmel Formation to the west (Havholm et al. 1993). Whereas the eolian accumulations in the western Sahara have little preservation potential, these same accumulations are preserved on the continental shelf, where they were transgressed by sea-level rise following the last glacial maximum (Sarnthein 1978). The dune field at White Sands, New Mexico, has a several-meter-thick subsurface record that apparently formed with the relative rise of the water table within a subsiding basin (Kocurek et al. 2007). On Earth, the dynamics of tectonism, eustasy, and climate drive the temporal and spatial nature of preservation. With planetary resurfacing, essentially no preservation is permanent (e.g., the once preserved Jurassic record is largely uplifted and erosional now).

\section{Mars}

Preservation of eolian accumulations on Mars has been infrequently addressed, and the geometries of bodies of strata and their "containers" are poorly known. In the absence of tectonism and eustasy, preservation on Mars can be envisioned by burial by lava flows, impact debris, and continued eolian and other accumulations in topographic basins, such as craters. It is plausible that initial preservation of the Burns formation occurred through an areal rise in 
A

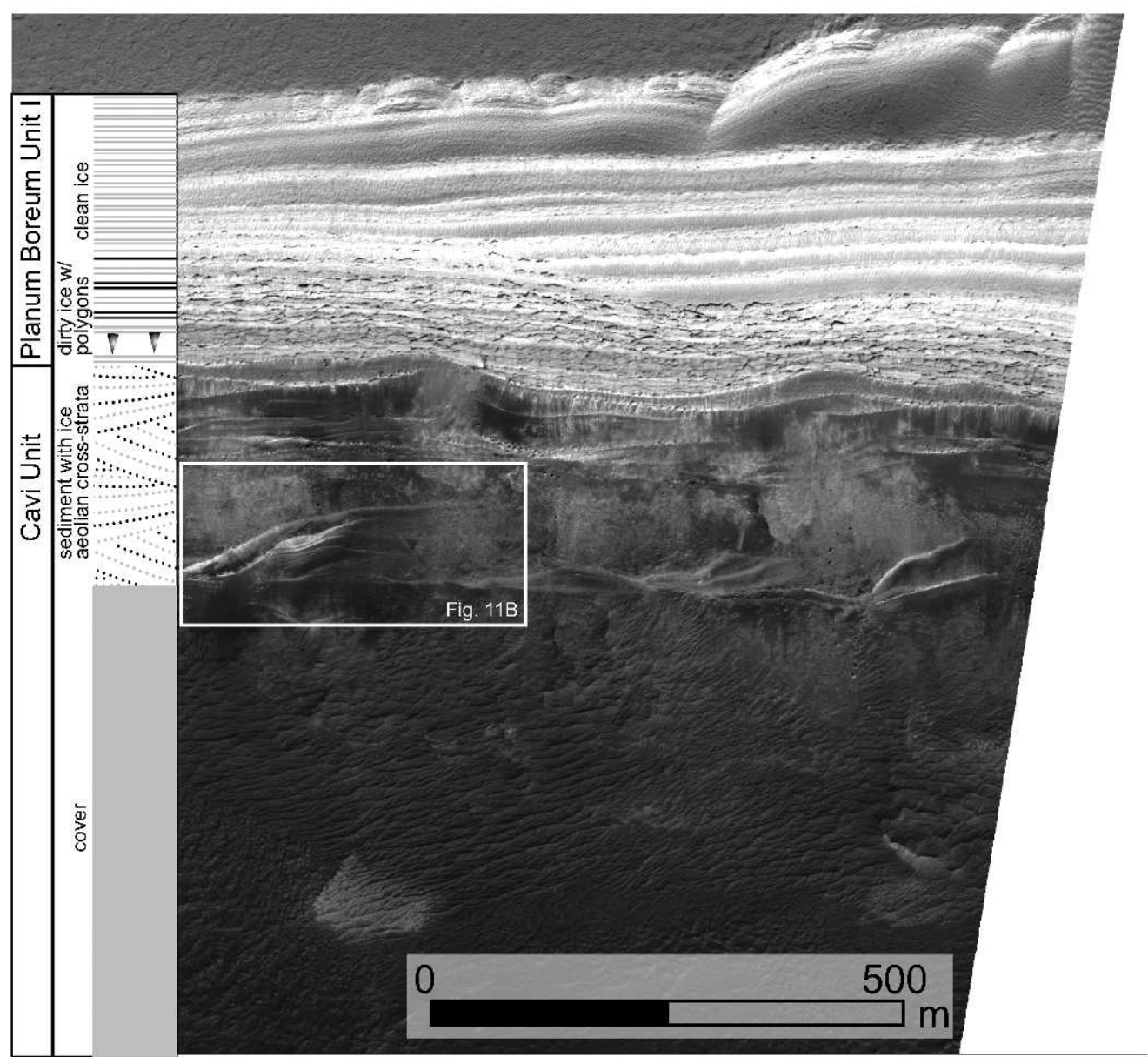

B

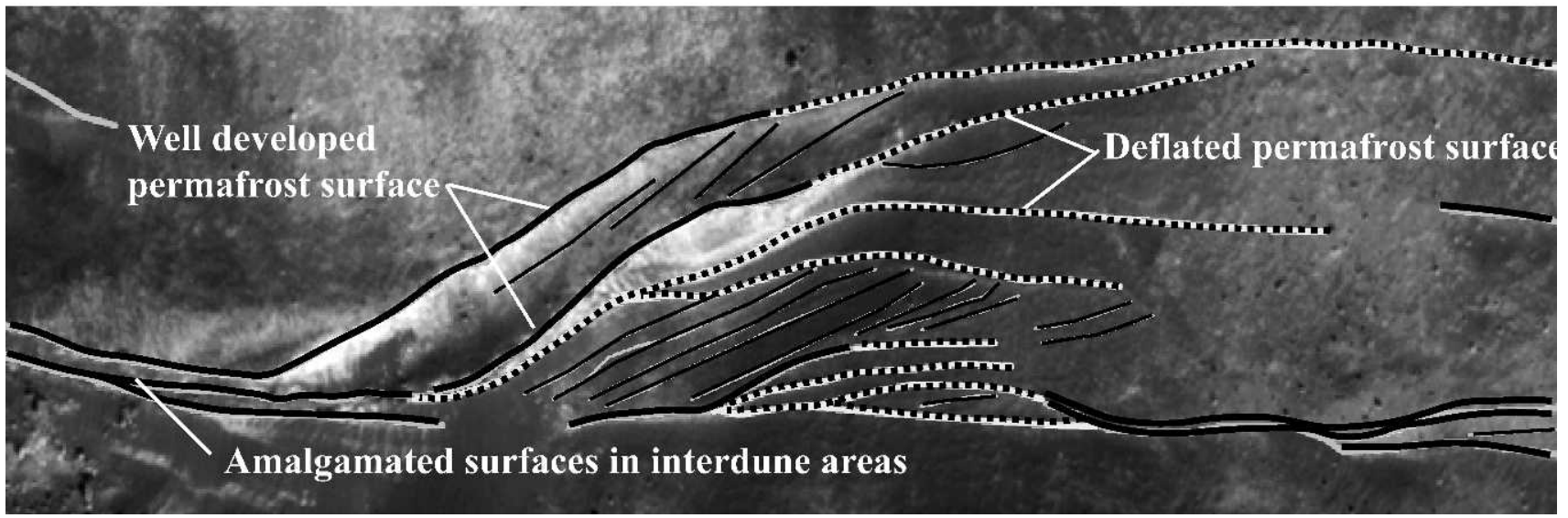

FIG. 11.-Accumulation and preservation of eolian cross-strata in the Planum Boreum cavi unit, north polar region of Mars. (A) Section shows upward gradation of sediment dune topography into layers of dirty ice that conform to underlying dune topography, then to layered ice. (B) Dune topography showing the stacking of dune stoss and lee deposits separated by permafrost surfaces, interpreted to represent cyclic dune activation and stabilization. Accumulation occurs because of the stabilizing effects of freezing. Preservation of the accumulations occurred with continued ice-sediment layering. Preservation space is currently being lost as the ice cap retreats and the underlying cavi unit erodes. HiRISE Image TRA_000863_2640. 


\section{Preservation of Aeolian Accumulations: Earth}

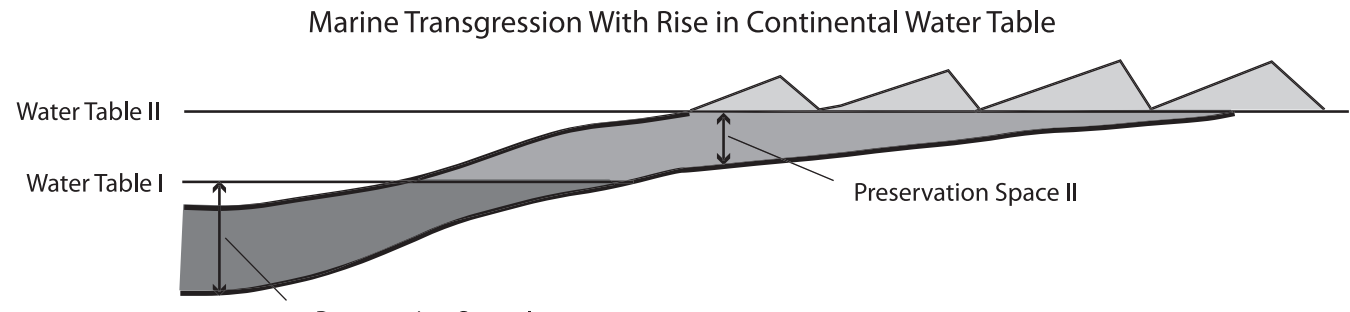

Preservation Space I
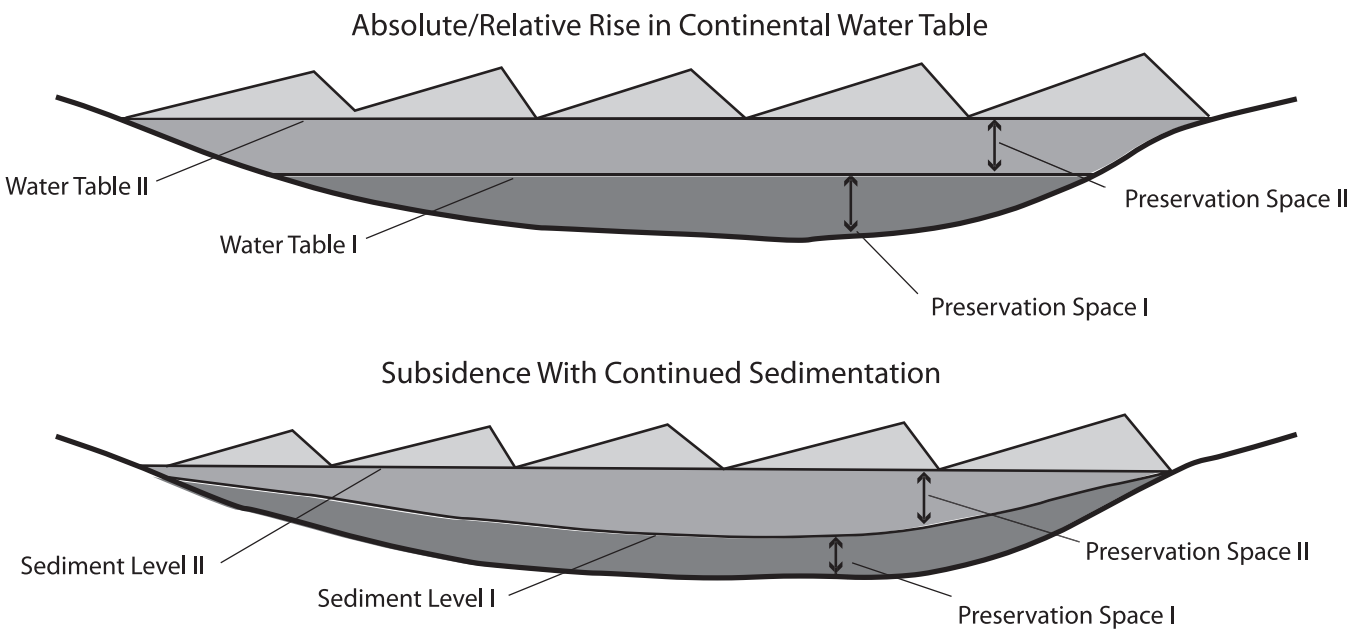

FIG. 12.-Modes of preservation of eolian accumulation on Earth. See text for discussion.

the water table, but the regional context of the unit is unknown. Grotzinger et al. (2005) suggested that the surface bounding the region around the Opportunity landing site is a prominent deflated stratigraphic contact. Preservation and loss of "preservation space" of the cavi unit in the north polar region of Mars has been explained as a function of climatic change (Byrne and Murray 2002, Fishbaugh and Head 2005). As described above, accumulation of the cavi unit is interpreted to have occurred through the cyclic stabilization of dunes through freezing and permafrost development. These dune accumulations are clearly transitional upward into the overlying layered ice cap accumulation (Planum Boreum 1 Unit; Fishbaugh and Head 2005, Tanaka et al. 2008). Preservation of the cavi accumulations was, therefore, by burial beneath the growing ice cap. Retreat of the ice cap has resulted in loss of preservation space and extensive erosion of the unit (Byrne and Murray 2002, Fishbaugh and Head 2005).

\section{Questions}

Given the absence of plate tectonism and eustasy on Mars, preservation must be envisioned differently on Mars than on Earth. Crater tectonism and preservation of eolian accumulations within crater basins is one fairly ready substitution. Climatic change, however, emerges as a significant driver of preservation dynamics, as evident by the cavi unit and probably elsewhere on Mars. At the planetary scale, however, preservation of eolian and other accumulations on Mars takes on a different relevance than on Earth. Where even Noachian depositional systems are still evident on the surface and planetary resurfacing occurs at Earth "deep time" scales, what defines preservation? Are surface dune fields stabilized by freezing or permafrost preserved because they remain undisturbed for millions of years? The Olympia Undae Dune Field may well be contemporary to the Jurassic Navajo Sandstone. Should preservation of Mars not be considered in time units, but rather be evident only by the creation of a stratigraphic record? Are there planetary rates and processes of resurfacing that define preservation on Mars?

\section{CONCLUSIONS}

Mars is the most eolian-dominated planet in the solar system, and eolian processes, along with cryogenic processes, may well be the primary drivers in planetary resurfacing. A simplified, source-to-sink comparison of eolian systems on Earth and Mars serves to underscore how little is understood about Martian eolian systems, even as Earth systems are far from totally understood. More importantly, however, this comparison demonstrates how the governing principles of eolian systems are manifested differently on Earth and Mars because of different planetary boundary conditions.

The planetary boundary conditions that yield sediment for eolian systems on Earth are absent, at least currently, on Mars, thus raising the fundamental question of how sediment is generated on Mars. Martian boundary conditions do not include loss of sediment from the surface through tectonism, burial in deep subsiding basins, or transport to oceanic basins. Sediment on Mars probably reflects early planetary history, when Mars was more similar to Earth, subsequent to very slow weathering processes and episodic generation during climatic cycles, impacts, and outflow events. Differences in planetary rock cycles may 
be manifested on Mars by direct deflation of grains from indurated strata where ice is the primary cementing agent and weathering occurs through sublimation during climatic cycles.

Regardless of how sediment is generated on Mars, eolian transport events are probably episodic because they require the coincidence of a wind capable of transporting sand and the availability of this sediment. The primary impact of the low-density atmosphere is that winds capable of sand transport are relatively rare. The cause of these winds is poorly known, but factors that increase air density may be more important than on Earth. Local katabatic winds that form over the highlands and polar ice caps, for example, may be more important for sediment transport than are planetary wind belts. Because of widespread permafrost, sediment availability is probably episodic, only occurring with periods of sublimation.

In spite of planetary differences in sediment production and grain transport, the eolian systems of Earth and Mars appear to largely converge with the emergence of dune topography. Within the hierarchy of the eolian transport system, dune-flow and dune-dune interactions are very similar on Earth and Mars, as manifested by dune morphologies, secondary flow over the bedforms, and pattern ordering through dune interactions. The implication is that dunes and their rock record can be interpreted by principles used on Earth, allowing for spatial comparisons and the development of a chronology of planetary change.

It is likely that most accumulation of eolian strata on Mars has occurred as dry systems, in which flow decelerates into topographic basins, which on Mars are commonly craters. Wet-system accumulation, as shown by the Burns formation at Endurance Crater, should be restricted to early planetary history. The most striking manifestation of a stabilizing system on Mars is accumulation within the cavi unit. The dynamics of stabilization by permafrost development in the cavi are analogous to the niche occupied by vegetation in stabilizing systems on Earth.

Although Earth-style preservation of eolian accumulations occurs on Mars with burial within topographic basins - albeit many of the basins arise through impact and not subsidence-the concept of preservation is challenged on Mars, where "deep-time" events can remain pristine on the surface. In restricting preservation to generation of a stratigraphic record, the preservation of cavi-style eolian accumulation by burial beneath the polar ice cap is significant because climatic cycles, and not tectonic nor eustatic cycles, have driven the preservation dynamics.

\section{ACKNOWLEDGMENTS}

This material is partly based upon work supported by the National Science Foundation under Award No. 0846233 to R.C. Ewing. We are grateful to Ken Tanaka and Ed Simpson for their constructive comments in reviewing the manuscript.

\section{REFERENCES}

Almeida MP, Parteli EJR, Andrade JS, Herrmann HJ. 2008. Giant saltation on Mars. Proceedings of the National Academy of Science 105:6222-6226.

Alpers CN, Brimhall GH. 1988. Middle Miocene climatic change in the Atacama Desert, northern Chile: Evidence from supergene mineralization at La Escondida. Bulletin Geological Society of America 100:1640-1656.

Anderson FS, Greeley R, Xu P, Lo E. 1999. Assessing the Martian surface distribution of aeolian sand using a Mars general circulation model. Journal of Geophysical Research 104:18991-19002.

Bagnold RA. 1941. The Physics of Blown Sand and Desert Dunes: Chapman and Hall, London.

Bandfield JL, Feldman WC. 2008. Martian high latitude permafrost depth and surface cover thermal inertia distributions. Journal of Geophysical Research 113, E08001, doi:10.1029/2007JE003007

Bell JF, Squyres SW, Arvidson RE, Arneson HM, Bass D, Blaney D, Cabrol N,
Calvin W, Farmer J, Farrand WH, Goetz W, Golombek M, Grant JA, Greeley R, Guinness E, Hayes AG, Hubbard MYH, Herkenhoff KE, Johnson MJ, Johnson JR, Joseph J, Kinch KM, Lemmon MT, Li R, Madsen MB, Maki JN, Malin M, McCartney E, McLennan S, McSween HY, Ming DW, Moersch JE, Morris RV, Noe Dobrea EZ, Parker TJ, Proton J, Rice JW, Seelos F, Soderblom J, Soderblom LA, Sohl-Dickstein JN, Sullivan RJ, Wolff MJ, Wang A. 2004. Pancam multispectral imaging results from the Spirit rover at Gusev crater. Science 305:800-806.

Beveridge C, Kocurek G, Ewing RC, Lancaster N, Morthekai P, Singhvi AK, Mahan SA. 2006. Development of spatially diverse and complex dune-field patterns: Gran Desierto Dune Field, Sonora, Mexico. Sedimentology 53:1391-1409.

Bibring JP, Langevin Y, Mustard J, et al. 2006. Global mineralogical and aqueous Mars history derived from OMEGA/Mars Express data. Science 312:400-404.

Bishop MA. 2007. Point pattern analysis of north polar crescentic dunes, Mars: A geography of dune self-organization. Icarus 191:151-157.

Bluck BJ, Ward JD, Cartwright J, Swart R. 2007. The Orange River, southern Africa: An extreme example of a wave-dominated sediment dispersal system in the south Atlantic Ocean. Journal of the Geological Society 164:341-351.

Blum M, Kocurek G, Deynoux M, Lancaster N, Price D, Pion JC. 1998. Quaternary wadi, lacustrine, aeolian depositional cycles and sequences, Chott Rharsa Basin, southern Tunisia. In Alsharhan A, Glennie K, Whittle G, Kendall C (Editors). Quaternary Deserts and Climatic Change: A.A. Balkema, Rotterdam, The Netherlands. p. 539-552.

Bourke MC, Bullard JE, Barbouin-Jha OS. 2004. Aeolian sediment transport pathways and aerodynamics at troughs on Mars. Journal of Geophysical Research 109, E07005, doi:10.1029/2003JE002155

Bourke MC, Edgett KS, Cantor BA. 2008. Recent aeolian dune changes on Mars. Geomorphology 94:247-255.

Bourke MC, Ewing RC, Finnegan D, McGowan HA. 2009. Sand dune movement in the Victoria Valley, Antarctica. Geomorphology 109:148-160.

Breed CS, Grolier MJ, McCauley JF. 1979. Morphology and distribution of common 'sand' dunes on Mars: Comparison with the Earth. Journal of Geophysical Research 84:8183-8204.

Bridges NT, Geissler PE, McEwen AS, Thomson BJ, Chuang FC, Herkenhoff KE, Keszthelyi LP, Alonso-Martinez S. 2007. Windy Mars: A dynamic planet as seen by the HiRise camera. Geophysical Research Letters 34, L23205, doi:10.1029/2007GL031445

Bristow CS, Augustinus PC, Wallis IC, Jol HM, Rhodes EJ. 2010a. Investigation of the age and migration of reversing dunes in Antarctica using GPR and OSL, with implications for GPR on Mars. Earth and Planetary Science Letters 289:30-42.

Bristow CS, Jol HM, Augustinus P, Wallis I. 2010b. Slipfaceless 'whaleback' dunes in a polar desert, Victoria Valley, Antarctica: Insights from ground penetrating radar. Geomorphology 114:361-372.

Brookfield ME. 1977. The origin of bounding surfaces in ancient aeolian sandstones. Sedimentology 24:303-332.

Byrne S, Dundas CM, Kennedy MR, et al. 2009. Distribution of mid-latitude ground ice on Mars from new impact craters. Science 325:1674-1676.

Byrne S, Murray BC. 2002. North polar stratigraphy and the paleo-erg of Mars. Journal of Geophysical Research 107, E6, 5044, doi:10.1029/2001JE001615

Cantor B, Kanak AKM, Edgett KS. 2006. Mars Orbiter Camera observations of Martian dust devils and their tracks (September 1997 to January 2006) and evaluation of theoretical vortex models. Journal of Geophysical Research 111: E12002, doi:10.1029/2006JE002700

Claudin P, Andreotti B. 2006. A scaling law for aeolian dunes on Mars, Venus, Earth, and for subaqueous ripples. Earth and Planetary Science Letters 252:30-44.

Crabaugh M, Kocurek G. 1993. Entrada Sandstone: An example of a wet aeolian system. In Pye K (Editor). The Dynamics and Environmental Context of Aeolian Sedimentary Systems: Geological Society, London. Special Publication 72. p. 103-126.

Crabaugh M, Kocurek G. 1998. Continental sequence stratigraphy of a wet eolian system: A key to relative sea-level change. In Shanley KW, McCabe PJ (Editors). Relative Role of Eustasy, Climate, and Tectonism in Continental Rocks: SEPM Society for Sedimentary Geology, Tulsa, OK, Special Publication 59. p. 213-228. 
Derickson D, Kocurek G, Ewing RC, Bristow C. 2008. Origin of a complex and spatially diverse dune-field pattern, Algodones, southeastern California. Geomorphology 99:186-204.

Edgett KS, Blumberg DG. 1994. Star and linear dunes on Mars. Icarus 112:448-464

Edgett KS, Christensen PR. 1991. The particle size of Martian aeolian dunes. Journal of Geophysical Research 96:22765-22776, doi:10.1029/91JE02412

Edgett KS, Malin MC. 2000. New views of Mars eolian activity, materials, and surface properties: Three vignettes from the Mars Global Surveyor Mars orbiter camera. Journal of Geophysical Research 105(E1):1623-1650.

Edwards CS, Bandfield JL, Christensen PR, Fergason RL. 2009. Global distribution of bedrock exposures on Mars using THEMIS high-resolution thermal inertia. Journal of Geophysical Research 114: E11001, doi:10.1029/ 2009JE003363

Elbelrhiti H, Andreotti B, Claudin P. 2008. Barchan dune corridors: Field characterization and investigation of control parameters. Journal of Geophysical Research 113: F02S15, doi:10.1029/2007JF000767

Eriksson KA, Simpson EL. 1998. Controls on spatial and temporal distribution of Precambrian eolianites. Sedimentary Geology 120:275-294.

Ewing RC, Kocurek G. 2010a. Dune interactions and dune-field pattern development: White Sands Dune Field, New Mexico, USA. Sedimentology 57:1199-1219.

Ewing RC, Kocurek G. 2010b. Aeolian dune-field pattern boundary conditions. Geomorphology 114:175-187.

Ewing RC, Kocurek G, Lake L. 2006. Pattern analysis of dune-field parameters. Earth Surface Processes and Landforms 31:1176-1191.

Ewing RC, Peyret A, Kocurek G, Bourke M. 2010. Recent transporting winds and dune-field pattern formation in the Olympia Undea Dune Field, Mars. Journal of Geophysical Research 115: E08005, doi:10.1029/2009JE003526

Feldman WC, Bourke MC, Elphic RC, Maurice S, Bandfield J, Prettyman TH, Diez B, Lawrence DJ. 2008. Hydrogen content of sand dunes within Plympia Undae. Icarus 196:422-432, doi:10.1016/j.icarus.2007.08.044

Fenton LK. 2005. Potential sand sources for dune fields in Noachis Terra, Mars. Journal of Geophysical Research 110: E11004, doi:10.1029/2005JE002436

Fenton LK, Bandfield JL, Ward JL. 2003. Aeolian processes in Proctor crater on Mars: Sedimentary history as analyzed from multiple data sets. Journal of Geophysical Research 108: E12, 5129, doi:10.1029/2002JE002015

Fenton LK, Hayward RK. 2010. Southern high latitude dune fields on Mars: Morphology, aeolian inactivity, and climate change. Geomorphology 121:98121.

Fishbaugh KE, Head JW. 2005. Origin and characteristics of the Mars north polar basal unit and implications for polar geologic history. Icarus 174:444474.

Forrest SP, Haff PK. 1992. Mechanics of wind ripple stratigraphy. Science 255:1240-1243

Frank A, Kocurek G. 1996a. Airflow up the stoss slope of sand dunes: Limitations of current understanding. Geomorphology 17:47-54.

Frank A, Kocurek G. 1996b. Toward a model for airflow on the lee side of aeolian dunes. Sedimentology 43:451-458.

Fryberger SG, Krystinik LF, Schenk CJ. 1990. Tidally flooded back barrier dunefield, Guerrero Negro area, Baja California, Mexico. Sedimentology 37:23-43.

Gibson EK, Wentworth SJ, McKay DS. 1983. Chemical weathering and diagenesis of a cold desert soil from Wright Valley, Antarctica: An analog of Martian weathering processes. Proceedings of the Lunar Science Conference 13:A912-A928.

Golombek MP, Bridges NT. 2000. Erosion rates on Mars and implications for climate change: Constraints from the Pathfinder landing site. Journal Geophysical Research 105:1841-1853.

Golombek MP, Grant JA, Crumpler LS, Greeley R, Arvidson RE, Bell JF, Weitz CM, Sullivan R, Christensen PR, Soderblom LA, Squyres SW. 2006. Erosion rates at the Mars Exploration Rover landing sites and long-term climate change on Mars. Journal of Geophysical Research 111: E12S10, doi:10. 1029/2006JE002754

Golombek MP, Robinson K, McEwen A, Bridges N, Ivanov B, Tornabene L, Sullivan R. 2010. Constraints on ripple migration at Meridiani Planum from Opportunity and HiRISE observations of fresh craters. Journal of Geophysical Research 115: E00F08, doi:10.1029/2010JE003628.
Greeley R, Arvidson RE, Barlett PW, et al. 2006. Gusev crater: Wind-related features and processes observed by the Mars Exploration Rover Spirit. Journal of Geophysical Research 111: E02S09, doi:10.1029/2005JE002491

Greeley R, Kraft MD, Kuzmin RO, Bridges NT. 2000. Mars Pathfinder landing site: Evidence for a change in wind regime from lander and orbitor data. Journal of Geophysical Research 105(E1):1829-1840.

Greeley R, Lancaster N, Lee S, Thomas P. 1992. Martian aeolian processes, sediments and features. In Kieffer HH, Jakowsky B, Snyder C, Matthews M (Editors). Mars: The University of Arizona Press, Tucson. p. 730-766.

Greeley R, Leach R, White B, Iverson J, Pollack J. 1980. Threshold wind speeds for sand on Mars: Wind tunnel experiments. Geophysical Research Letters $7: 121-124$

Greeley R, Squyres SW, Arvidson RE, et al. 2004. Wind-related processes detected by the Spirit rover at Gusev crater, Mars. Science 305:810-813.

Grotzinger JP, Arvidson RE, Bell JF, et al. 2005. Stratigraphy and sedimentology of a dry to wet eolian depositional system, Burns Formation, Meridiani Planum, Mars. Earth and Planetary Science Letters 240:11-72.

Havholm KG, Blakey RC, Capps M, Jones LS, King DD, Kocurek G. 1993. Aeolian genetic stratigraphy: An example from the Middle Jurassic Page Sandstone, Colorado Plateau. In Pye K, Lancaster N (Editors). Aeolian Sediments: Ancient and Modern Blackwell, Oxford, UK. p. 87-107.

Hayward RK, Mullins KF, Fenton LK, Hare TM, Titus TN, Bourke MC, Colaprete A, Christensen PR. 2007. Mars global digital dune database and initial science results. Journal of Geophysical Research 112: E11007, doi:10. 1029/2007JE002943

Hersen P, Douady S. 2005. Collisions of barchans dunes as a mechanism of size regulation. Geophysical Research Letters 32: L21404, doi:10.1029/ 2005GL024179

Howard AD. 2000. The role of eolian processes in forming surface features of the Martian Polar Layered Deposits. Icarus 144:267-288.

Hunter RE. 1977. Basic types of stratification in small eolian dunes. Sedimentology 24:361-387.

Hunter RE, Rubin DM. 1983. Interpreting cyclic cross-bedding, with an example from the Navajo Sandstone. In Brookfield ME, Ahlbrandt TS (Editors). Eolian Sediments and Processes, Developments in Sedimentology 38:429-454.

Hurowitz JA, McLennan SM. 2007. A 3.5 Ga record of water-limited, acidic weathering conditions on Mars. Earth and Planetary Science Letters 260:432-443

Iverson JD, White BR. 1982. Saltation threshold on Earth, Mars and Venus. Sedimentology 29:111-119.

Jerolmack DJ, Mohrig D, Grotzinger JP, Fike DA, Watters WA. 2006. Spatial grain size sorting in eolian ripples and estimation of wind conditions on planetary surfaces: Application to Meridiani Planum, Mars. Journal of Geophysical Research 111: E12S02, doi:10/1029/2005JE002544

Kocurek G. 1988. First-order and super bounding surfaces in eolian sequences - bounding surfaces revisited. Sedimentary Geology 56:193-206.

Kocurek G. 1991. Interpretation of ancient eolian sand dunes. Annual Review of Earth and Planetary Science 19:43-75.

Kocurek G. 1996. Desert Aeolian systems. In Reading HG (Editor). Sedimentary Environments: Processes, Facies and Stratigraphy, 3rd ed.: Blackwell, Oxford, UK. p. 125-153.

Kocurek G. 1998. Aeolian system response to external forcing factors-A sequence stratigraphic view of the Sahara region. In Alsharhan AS, Glennie KW, Whittle GL, Kendall CG StC (Editors). Quaternary Deserts and Climatic Change: A.A. Balkema, Rotterdam, The Netherlands. p. 327-337.

Kocurek G. 1999. The aeolian rock record (Yes, Virginia, it exists, but it really is rather special to create one). In Goudie A, Livingston I (Editors). Aeolian Environments, Sediments and Landforms: John Wiley, London. p. 239-259.

Kocurek G. 2003. Limits on extreme Eolian systems: Sahara of Mauritania and Jurassic Navajo Sandstone examples. In Chan M, Archer A (Editors). Extreme Depositional Environments: Mega End Members in Geologic Time: Geological Society of America Special Paper 370. p. 43-52.

Kocurek G, Carr M, Ewing R, Havholm KG, Nagar YC, Singhvi AK. 2007. White Sands Dune Field, New Mexico: Age, dune dynamics and recent accumulations. Sedimentary Geology 197:313-331.

Kocurek G, Deynoux M, Blakey RC, Havholm KG. 1991a. Amalgamated 
accumulations resulting from climatic and eustatic changes, Akchar Erg, Mauritania. Sedimentology 38:751-772.

Kocurek G, Ewing RC. 2005. Aeolian dune field self-organizationimplications for the formation of simple versus complex dune-field patterns. Geomorphology 72:94-105.

Kocurek G, Ewing RC, Mohrig D. 2010. How do bedform patterns arise? New views on the role of bedform interactions within a set of boundary conditions. Earth Surface Processes and Landforms 35:51-63.

Kocurek G, Havholm K. 1994. Eolian sequence stratigraphy—a conceptual framework. In Weimer P, Posamentier H (Editors). Siliciclastic Sequence Stratigraphy: American Association of Petroleum Geologists Memoir 58. p. 393-409.

Kocurek G, Knight J, Havholm K. 1991b. Outcrop and semi-regional threedimensional architecture and reconstruction of a portion of the eolian Page Sandstone (Jurassic). In Miall A, Tyler N (Editors). Three-Dimensional Facies Architecture of Terrigenous Clastic Sediments and its Implications for Hydrocarbon Discovery and Recovery: SEPM Society for Sedimentary Geology Concepts in Sedimentology and Paleontology 3, Tulsa, OK. p. 2543.

Kocurek G, Lancaster N. 1999. Aeolian system sediment state: Theory and Mojave Desert Kelso dune field example. Sedimentology 46:505-515.

Kocurek G, Robinson NI, Sharp JM. 2001. The response of the water table in coastal aeolian systems to changes in sea level. Sedimentary Geology 139:113.

Kocurek G, Townsley M, Yeh E, Havholm K, Sweet ML. 1992. Dune and dunefield development on Padre Island, Texas, with implications for interdune deposition and water-table-controlled accumulation. Journal of Sedimentary Petrology 62:622-635.

Kok JF. 2010. Differences in the wind speed required for initiation versus continuation of sand transport on Mars: Implications for dunes and dust storms. Physical Review Letters 104: doi:10.1103/PRL104.074502

Lancaster N. 1995. Geomorphology of Desert Dunes: Routledge, London. $290 \mathrm{p}$.

Lancaster N, Ollier CD. 1983. Sources of sand for the Namib Sand Sea. Zeitschrift fur Geomorphologie Supplementband 45:71-83.

Landry W, Werner BT. 1994. Computer simulations of self-organized wind ripple patterns. Physica D 77:238-260.

Langbein W, Schumm S. 1958. Yield of sediment in relation to mean annual precipitation. Transactions of the American Geophysical Union 39:10761084 .

Langford R. 2003. The Holocene history of the White Sands Dune Field and influence on eolian deflation and playa lakes. Quaternary International 104:31-39.

Lee P, Thomas P. 1995. Longitudinal dunes on Mars: Relation to current wind regimes. Journal of Geophysical Research 36(E3):5381-5395.

Levy JS, Head JW, Marchant DR. 2009. Cold and dry processes in the Martian Arctic: Geomorphic observations at the Phoenix landing site and comparisons with terrestrial cold desert landforms. Geophysical Research Letters 36: L21203, doi:10.1029/2009GL04634

Levy JS, Marchant DR, Head JW. 2006. Distribution and origin of patterned ground on Mullins Valley debris-covered glacier, Antarctica: The roles of ice flow and sublimation. Antarctica Science 18:385-397.

Madden MEE, Bodnar RJ, Rimstidt JD. 2004. Jarosite as an indicator of waterlimited chemical weathering on Mars. Nature 431:821-823.

Malin MC, Edgett KS. 2006. Present-day impact cratering rates and contemporary gully activity on Mars. Science 314:1573-1577.

Marchant DR, Head JW. 2007. Antarctic dry valleys: Microclimate zonation, variable geomorphic processes, and implications for assessing climate change on Mars. Icarus 192:187-222.

Marchant DR, Lewis GH, Phillips WC, Moore EJ, Souchez R, Landis GP. 2002. Formation of patterned-ground and sublimation till over Miocene glacier ice in Beacon Valley, Antarctica. Geological Society America Bulletin 114:718730 .

Maria MRV Sta, Rafkin SCR, Michaels TI. 2006. Numerical simulation of atmospheric bore waves on Mars. Icarus 185:383-394.

McLennan SM, Grotzinger JP. 2008. The sedimentary rock cycle of Mars. In Bell JF (Editor). The Martian Surface: Composition, Mineralogy, and
Physical Properties: Cambridge University Press, Cambridge, UK. p. 541577.

Metz JM, Grotzinger JP, Rubin DM, Lewis KW, Squyres SW, Bell JF. 2009. Sulfate-rich eolian and wet interdune deposits, Erebus Crater, Meridiani Planum, Mars. Journal Sedimentary Research 79:247-264.

Mountney NP, Jagger A. 2004. Stratigraphic evolution of an aeolian erg margin system: The Permian Cedar Mesa Sandstone, SE Utah, USA. Sedimentology 51:713-743.

Nanson GC, Price DM, Short SA. 1992. Wetting and drying of Australia over the past $300 \mathrm{ka}$. Geology 20:791-794.

Nickling WG, McKenna Neuman C, Lancaster N. 2002. Grainfall processes in the lee of transverse dunes, Silver Peak, Nevada. Sedimentology 49:191-209.

Paola C, Borgman L. 1991. Reconstructing random topography from preserved stratification. Sedimentology 38:553-565.

Parteli EJR, Herrmann HJ. 2007. Dune formation on present Mars. Physical Review E-Statistical, Nonlinear, and Soft Matter Physics 76(4) $041307-$ 041315.

Presley MA, Christensen PR. 1997. Thermal conductivity measurements of particle material 2. Results. Journal of Geophysical Research 102(E2):65516566.

Rubin DM. 1987. Cross-bedding, bedforms, and paleocurrents: SEPM Society for Sedimentary Geology, Concepts in Sedimentology and Paleontology 1. Tulsa, OK. 187 pp.

Rubin DM, Hunter RE. 1982. Bedform climbing in theory and nature. Sedimentology 29:121-138.

Rubin DM, Hunter RE. 1987. Bedform alignment in directionally varying flows. Science 237:276-278.

Rubin DM, Ikeda H. 1990. Flume experiments on the alignment of transverse, oblique, and longitudinal dunes in directionally varying flows. Sedimentology 37:673-684.

Sarnthein M. 1978. Sand deserts during glacial maximum and climatic optimum. Nature 272:43-46.

Schatz V, Tsoar H, Edgett KS, Parteli EJR, Herrmann H. 2006. Evidence for indurated sand dunes in the Martian north polar region. Journal of Geophysical Research 111: E04006, doi:10.1029/2005JE002514

Schorghofer N, Edgett KS. 2006. Seasonal surface frost at low latitudes on Mars. Icarus 180:321-334.

Silvestro S, Di Achille G, Ori GG. 2010a. Dune morphology, sand transport pathways and possible source areas in east Thaumasia region (Mars). Geomorphology 121:84-97.

Silvestro S, Fenton LK, Vaz DA, Bridges NT, Ori GG. 2010b. Ripple migration and dune activity on Mars: Evidence for dynamic wind processes. Geophysical Research Letters 37: L20203, doi:10.1029/2010GL044743

Singhvi AK, Kar A. 2004. The aeolian sedimentation record of the That Desert. Proceedings of the Indian Academy of Sciences 11:371-401.

Spiga A. 2011. Elements of comparison between Martian and terrestrial mesoscale meteorological phenomena: Katabatic winds and boundary layer convection. Planetary and Space Science, 59:915-922.

Sullivan R, Arvidson R, Bell JE, Gellert R, Golombek M, Greeley R, Herkenhoff K, Johnson J, Thompson S, Wheeley P, Wray J. 2008. North polar region of Mars: Wind-driven particle mobility on Mars: Insights from Mars exploration rover observations at "El Dorado" and surroundings at Gusev crater. Journal of Geophysical Research 113: E06S07, doi:10.1029/ 2008JE003101

Sweet ML, Kocurek G. 1990. An empirical model of eolian dune lee-face dynamics. Sedimentology 37:1023-1038.

Tanaka KL, Fortezzo CM, Hayward RK, Rodriguez JA, Skinner JA. 2010. History of plains resurfacing in the Scandia region of Mars. Planetary and Space Science, doi:10.1016/J.PSS.2010.11.004

Tanaka KL, Rodriguez JA, Skinner JA, Bourke MC, Fortezzo CM, Herkenhoff KE, Kolb EJ, Okubo CH. 2008. North polar region of Mars: Advances in stratigraphy, structure, and erosional modification. Icarus 196:318-358.

Tosca NJ, Knoll AH. 2009. Juvenile chemical sediments and the long term persistence of water at the surface of Mars. Earth and Planetary Science Letters 286:379-386.

Tsoar H, Greeley R, Peterfreund AR. 1979. Mars: The north polar sand sea and related wind patterns. Journal of Geophysical Research 84(B14):8167-8180. Walker IJ, Nickling WG. 2002. Dynamics of secondary airflow and sediment 
transport over and in the lee of transverse dunes. Progress in Physical Geography 26:47-75.

Walker IJ, Nickling WG. 2003. Simulation and measurement of surface shear stress over isolated and closely spaced transverse dunes in a wind tunnel. Earth Surface Processes and Landforms 28:1111-1124.

Ward JD, Seely MK, Lancaster N. 1983. On the antiquity of the Namib. South African Journal of Science 79:175-183.

Wasson RJ, Rajaguru SN, Misra VN, Agrawal DP, Dhir RP, Singhvi AK, Rao KK. 1983. Geomorphology, Late Quaternary stratigraphy, and paleoclimatology of the Thar dunefield. Journal of Geomorphology 45:117-151.

Werner BT. 1995. Eolian dunes: Computer simulations and attractor interpretation. Geology 23:1107-1110.

Werner BT. 1999. Complexity in natural landform patterns. Science 284:102104.

Werner BT. 2003. Modeling landforms as self-organized, hierarchical dynamical systems. In Wilcock PR, Iverson RM (Editors). Predictions in Geomorphology, Geophysical Monograph 135: American Geophysical Union: Washington. p. 133-150.

Wilson I. 1973. Ergs. Sedimentary Geology 10:77-106.

Zimbelman JR. 2010. Transverse aeolian ridges on Mars: First results from HiRISE images. Geomorphology 121:22-29.

Zolotov MY, Mironenko MV. 2007. Timing of acid weathering on Mars: A kinetic-thermodynamic assessment. Journal of Geophysical Research 112: E07006, doi:10:1029/2006JE002882 